Portland State University

PDXScholar

7-18-1994

\title{
The Impact of the Donation Land Law Upon the Development of Oregon
}

\author{
Elwin Edward Grout \\ Portland State University
}

Follow this and additional works at: https://pdxscholar.library.pdx.edu/open_access_etds

Part of the History Commons

Let us know how access to this document benefits you.

\section{Recommended Citation}

Grout, Elwin Edward, "The Impact of the Donation Land Law Upon the Development of Oregon" (1994). Dissertations and Theses. Paper 4841.

https://doi.org/10.15760/etd.6717

This Thesis is brought to you for free and open access. It has been accepted for inclusion in Dissertations and Theses by an authorized administrator of PDXScholar. Please contact us if we can make this document more accessible: pdxscholar@pdx.edu. 


\section{THESIS APPROVAL}

The abstract and thesis of Elwin Edward Grout for the Masters of Arts in History were presented July 18, 1994, and accepted by the thesis committee and the department. COMMITTEE APPROVALS:

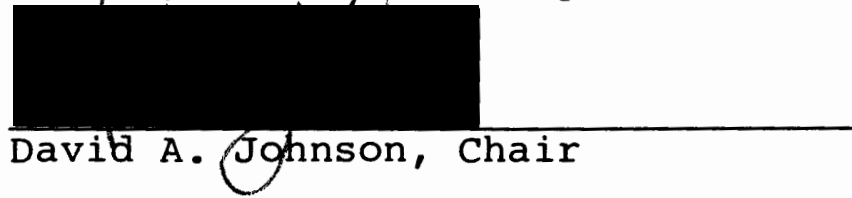

DEPARTMENT APPROVAL
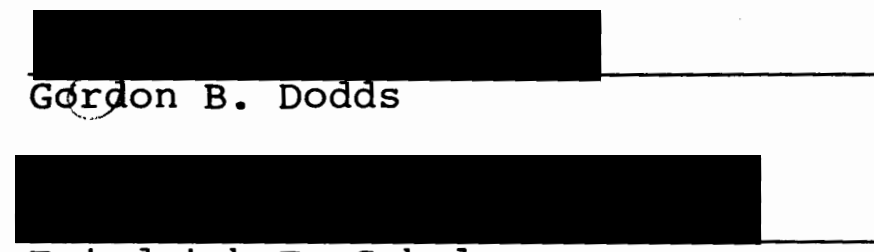

Friedrich E. Schuler

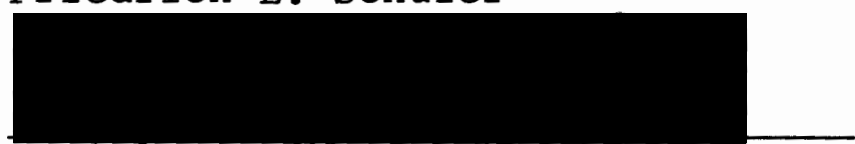

Daniel M. Johnsop

Representative of the office of Graduate styadies

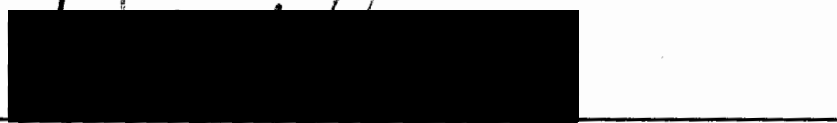

David A. Johnson, Chair

Department of History

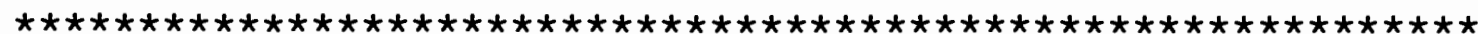

ACCEPTED FOR PORTLAND STATE UNIVERSITY BY THE LIBRARY

by

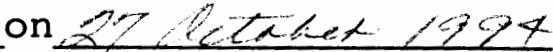


AN ABSTRACT OF THE THESIS OF Elwin Edward Grout for the Masters of Arts in History presented July 18, 1994.

Title: The Impact of the Donation Land Law Upon the Development of Oregon

The social and economic structure of oregon was influenced by the Donation Land Law. The Congressional law conferred upon early settlers to oregon 320 acres, 640 if married (and settled before December 1, 1850). Oregon attracted settlers who desired land and were uninterested in commercial agriculture. The oregon settlers who took advantage of the law were in a position to create their own society and economy.

The purpose of this thesis is to identify the social and economic structure created by the Donation Land pioneers and to identify their land disposition strategy. This thesis examined the fifty households that comprised the neighborhood of Fabritus R. Smith. The neighborhood is defined as the fifty households with whom Smith dealt in 1854 and 1855 .

The neighborhood of the 1850 s was a communally based society in which production was geared for household 
consumption, not commercial purposes. Settlers exchanged goods locally on a market that functioned on the basis of barter and a personal monetary system. The progression of time brought changes to the social and economic structure.

Lineal families working for themselves replaced nuclear families working in community as a productive force. Salem's growth, and the rise of a cash economy replaced exchange among households. Donation Land pioneers who deeded land to their children created the lineal family structure of society. The production of the lineal family remained geared for household consumption, not commercial purposes. The farmers of the second generation did not change their objective, only their strategy to meet the new economy. Two additional strategies were identified. Some Donation Land pioneers disposed of their land and used the money to pursue other ventures outside oregon. Other Donation Land pioneers sold their land and moved to salem. 
THE IMPACT OF THE DONATION LAND LAW UPON THE DEVELOPMENT OF OREGON

by

ELWIN EDWARD GROUT

A thesis submitted in partial fulfillment of the requirements for the degree of

\author{
MASTERS OF ARTS \\ in \\ HISTORY
}

Portland State University

1994 
TABLE OF CONTENTS

\section{PAGE}

LIST OF FIGURES........................ ii

INTRODUCTION ............................ CHAPTER

I DAILY LIFE ON THE OREGON FRONTIER

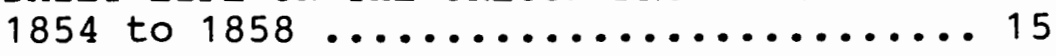

II HOUSEHOLDS :

THE FOUNDATION OF THE ECONOMY........ 37

III STEMMING THE TIDE:

THE GENERATION THAT TIME FORGOT....... 67

CONCLUSION............................ 92

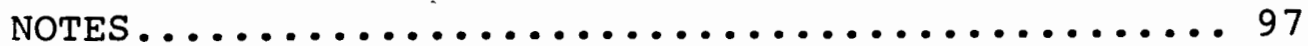

SELECTED BIBLIOGRAPHY.................... 106 


\section{LIST OF FIGURES}

1. Lorenz curve showing acreage and assessed value of real-estate,

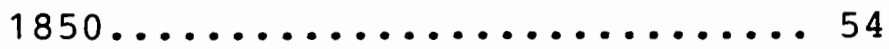

2. Lorenz curve showing assessed value of real-estate $1850,1860,1870 \ldots 57$ 


\section{INTRODUCTION}

The Donation Land Law greatly affected the economic and social development of oregon, and it is necessary to understand its influence in order to place oregon within the social history of the United States. Historians' interest in the social history of American rural communities is now only a few decades old. As in the case of the expanding population of America, social history began with the study of the colonies and the Chesapeake region. It slowly spread across the Appalachian Mountains, and into the Middle west. The two thousand mile trek across the Mississippi followed subsequently. Historians have studied agricultural societies to determine their social and economic structure. In the process they have found that in the early stages of social development the family was the primary social unit and that economic structure was related directly to social structure. Early settlers in agricultural societies directed family strategy toward reproduction of the family because economic structure was tied to the family strategy. over the centuries capitalism eventually developed; however, it did so only after economic and social transformations supplanted the family's productive role; 
farmers increasingly used outside markets for sale and purchase of produce alongside the rise of entrepreneurs in control of manufacturing. These transformations are central to the social history.

Historians examine social and economic structures against the backdrop of Marxian economic theory and neo-classical economic theory. Market historians, such as James Henretta and Christopher Clark, influenced by neo-classical economic theory, stress the importance of market influence on human behavior and seek to explain the spread of market processes through rural society. These scholars argue that capitalism arrived in North America with the first white settlers. Capitalism, as they define it, is measured by commercial expansion and household participation in commodity markets. Structural change occurred, as farmers participated in markets more fully. Within this school of thought, disagreement exists as to the amount of change exhibited within the capitalist economy. 1

Social historians, such as Hal Barron, Michael Merrill, and James Lemon, influenced by Marxian economic theory, seek to uncover patterns of economic and social behavior and relate this to the social relations of production and to social and political consciousness. 2 They ask, above all, whether capitalist ideology arrived with the early settlers, or whether it emerged in North 
America over the seventeenth and eighteenth centuries. Further, the character of rural economic exchange is central to social history. Social historians start with the distinction between use-value and exchange-value, a distinction drawn from Marxian theory. In use-value economies, households control the means of production. Most production is for household consumption, surpluses are entered into the market, and profits from these transactions are used to procure goods and services that the household cannot provide itself. According to the theory, the value of goods is determined by their utility to the producer. Markets exist to facilitate the distribution of goods through a region. Conversely, exchange-value economies are commercial economies where goods have a monetary value. Exchange is the ultimate purpose and profits are accumulated for their own sake. Every facet of the production process is directed toward a marketable crop. The income from the produce is used to fulfill household needs. ${ }^{3}$

Oregon developed differently than the above models. In fact, commercial agriculture developed in oregon before large-scale settlement by American farmers began. Oregon settlers rejected commercial agriculture after 1840 and some continued to resist economic change to 1900 . The period 1840 to 1900 found Oregon settlers resisting commercial agriculture first by developing a community 
of nuclear family households, and later by entrenching themselves within their lineal family. By 1900, however, commercial agriculture regained the dominant position in the oregon economy.

The initial strategy against commercial agriculture, nuclear families in community, developed as immigrants settled and needed assistance to provide for their needs. The community was comprised of several nuclear family households, working together to meet the subsistence needs of each family. The nuclear family consisted of a conjugal unit and children. From settlement through the 1850s, nuclear families dominated the oregon landscape. Households exchanged labor and produce in order to provide for all in the community. The social and economic structures of the farmers were directed toward reproduction of families.

But, in the second generation--roughly 1860 to $1900--$ lineal families supplanted the role of the settler period nuclear households. By lineal family I refer to the connections between parents and children, and between the grown children themselves. As in the case of the neighborhoods of cooperating nuclear families, each lineal family produced, above all, for its own subsistence needs, not markets. Lineal families grew out of the community. Marriages between the offspring of settlers strengthened kin connections and increased the resources available 
to each lineal family. This period, 1840 to 1900 , in this regard sets off two eras in oregon history where commercial agriculture and capitalism dominated the region. The Hudson's Bay Company came to dominate the markets of the Pacific Northwest in the $1820 \mathrm{~s}$, but was not the first to trade there. It came after the Russians, after the Spaniards, after the ventures of John Jacob Astor, and after the Northwesters. The motivation for exploitation came in the form of the Great Fur Rush. Although the $\mathrm{HBC}$ served as the government of the region, it was designed as a business whose primary goal was to make money for its stock holders. As such, markets were created and filled by the Company's presence in the Pacific Northwest. Settlement by Americans would have been even more difficult had it not been for the company' Chief Factor, Dr. John McLoughlin.

No history of the Northwest is complete without consideration of the Company. The Company's base of operations in the Pacific Northwest was Fort Vancouver. The Company's primary activity was the fur trade. It engaged in trade for furs with the indigenous population, and hired its own trappers. The Company also became involved in the lumber and salmon export business. In addition, the company produced its own food by cultivating the soil around its trading centers. Indeed, Fort Vancouver was reported to have 3000 fenced acres under 
cultivation in 1837.4

The earliest settlers of oregon were retired members of the Hudson's Bay Company. They farmed, and they sold their produce to the company. The HBC dominated the economy of Oregon until the 1840s. In September 1834, the Methodist missionary Jason Lee arrived at the Company's Fort Vancouver post. Lee chose to establish the mission in the willamette Valley, rather than in the interior of Oregon, as he had originally planned. The charitable nature of Lee's mission did not appear to McLoughlin to threaten the company's monopoly, and as a result, Lee's party was taken in and provided assistance. Indeed, for a decade after Lee's arrival, American settlers received assistance from McLoughlin. Settlers in oregon were without provisions when they arrived overland, and the Methodist Mission in oregon was unable to provide for the needs of the newcomers. The Company also siphoned off the surplus produce of the willamette valley farmers and sold it on markets it had established. 5

The Methodists received assistance from McLoughlin in order to survive. McLoughlin provided assistance contrary to his superiors' wishes. The earliest American settlers, out of necessity, traded with the Company, but as their numbers increased, their dependence upon the Company declined. In part out of distrust, the settlers began to provide for their own, and each small community 
planted crops with an eye to the promise of newcomers the next fall. Eventually, the Company lost its dominant position, and with its passing closed an early chapter in the history of agricultural society in oregon.

American immigration to oregon began in earnest during the 1840s. The majority of early settlers came from the Ohio River Valley and border states. There, the Depression of 1837 had undermined farmers' confidence in commercial agriculture. Speculation and agricultural prosperity prompted farmers to expand their farms by mortgaging their lands. Bank crises in Europe and America resulted in the calling in of loans and the suspension of specie payments. Many farmers were unable to pay off their mortgages during the panic and subsequently lost their lands and livelihoods. The depression created a deep suspicion of the monied interests on the part of farmers. Midwestern settlers in oregon sought to avoid a repetition of economic depression, but they still desired land. Their ideal was to reproduce their own productive order independent of the will of others. 6

In oregon, access to land was provided through the liberal provisions of the Donation Land Law. During August and September of 1850, Congress considered--and passed-"House Bill No. 250, being a bill to 'create the office of surveyor general of the public lands in oregon, and to provide for the survey, and to make donations to 
settlers of the said public lands'."7 The key provision granted 320 acres to any settler, who was a citizen, residing in Oregon before December 1,1850 . Mixed-blood Indians and foreign-born (who declared their intention to become naturalized) were allowed to claim an equal amount. Possession was contingent upon four years residence and cultivation. A married couple could claim a 640 acre tract, one-half of which was held by the wife in her own right. Congress provided a donation of the public lands equal to one-half of the above claim to settlers arriving after December 1,1850 and before December $1,1853.8$ The settlement date was later moved to December 1,1855 .

This law in effect affirmed the Land Law of the Oregon Provisional Government. That government's Organic Law of 1843 included provisions which allowed each individual to claim one square mile of land. The land law of the Provisional Government was based on previous bills senator Lewis Linn of Missouri introduced in Congress in 1841 and 1842. Oregon settlement did not wait for passage of the Linn bills. Linn's bills and resolutions varied in the size each individual could claim, but each provided a grant to induce settlement. In every aspect, the Linn Bills were a departure from existing land legislation. For example, the Pre-emption Act of 1841 allowed squatters the right of pre-emption, and first choice in the purchase 
of the land as they came on the market. ${ }^{9}$ subsequent Land legislation continued along the lines of the pre-emption Act in that they provided for the sale of Public Lands. The Donation Land Act was the only land law of its time that gave generous amounts of land to settlers. Congress intended the Donation Land Act to reward those settlers who had secured possession of oregon for the United States. 10 In effect, the Act gave oregon to the settlers to do with as they chose. Possession of the land required, simply, residence and cultivation. These stipulations determined who would migrate. Oregon provided solace to farmers who were desirous of farming outside of commercial markets. The Donation Act gave the families of Midwestern farmers the prospect of building a society that shielded them from the vagaries of commercial agriculture. With these objectives, farmers claimed the fertile valleys of western oregon and transformed Indian land into a Euro-American agricultural society.

The American settlers who were so rewarded commanded an advantageous position that allowed them to shape the society that developed. In turn, later arrivals were absorbed by the social order created by the Donation Land pioneers. For two generations many oregon farmers and their children resisted the lure of commercial agriculture, first by entrenching themselves in community, and later, 
by relying upon family connections. Other early settlers sold their Donation Land Claims and used the money to move on, or pursue other ventures. Not until the late nineteenth and early twentieth centuries did commercial agriculture regain a foothold in oregon.

This thesis documents the early development of oregon, both socially and economically, from settlement to the turning of the twentieth century, through a case study of a neighborhood bordering the town of salem. In the process, I have relied upon existing records from the period. Chapter one, recreates daily life on the oregon rural frontier. The daybook of Fabritus smith yields insight into the activities of one oregon farmer from 1854 to 1858 . Smith serves as a representative of his generation, testifying in the daily records of his life to a communally based society in which production was geared for household consumption.

Chapter Two characterizes the change that occurred within the Smith neighborhood (other neighborhoods may have differed). The demographic aspects of the neighborhood from 1850 to 1895 show that some of the settlers from the community of households that developed in the 1850 s later shifted to lineal families providing for themselves. This change in the social structure allowed those settlers in Smith's neighborhood to resist the pull of commercial agriculture. The strategy differed 
for some families. The household structure of society was the most significant aspect of the Smith neighborhood. For the purposes of this study, I define this neighborhood as the group of settlers with whom Smith dealt during 1854 and 1855 (as noted in his account book). The neighborhood was a homogeneous set of households with similar experiences that bound them into viable production units. This chapter also draws out age-sex characteristics, the age at marriage, and migratory patterns.

The nature of the changes that took place in the neighborhood is the focus of Chapter Three. This chapter examines the disposition of settlers' land, and the strategies that families used to provide for the second generation. I found the second generation lived differently than their parents, given the decline of the community, the rise of the lineal family, and the increased development of Salem as a commercial center. Change and persistence intermingled. The social and economic structure created by the Donation Land pioneers existed alongside a commercial entrepot.

Recent works of social history have examined rural social developments. In 1978, James Henretta set out to reconstruct the mentalite' of preindustrial American farmers. In his influential study, he argued that colonial husbandmen were not communally oriented. Nor were they 
prototypical modern men, or nascent capitalists frustrated in their attempts at capital accumulation by a lack of markets. Rather, Henretta held that preindustrial American farmers were first and foremost concerned with the family line. In Henretta's estimation, the success of these farmers was measured by their ability to pass a freehold or competence to their children. ${ }^{11}$

Michael Merrill expanded Henretta's ideas through Marxian theory. Merrill defined rural society as the product of a "household mode of production" distinct from simple commodity mode or a capitalist mode of production. By household mode of production, Merrill means that production "is planned with one eye on the needs of one's own household, and the other on the needs of neighboring households." Farmers' production was geared by social need. ${ }^{12}$

A synthesis of Merrill's and Henretta's conclusions existed in Smith's oregon neighborhood for two generations. These farmers produced for a social need. Even after the shift to the lineal family, production was geared to the needs of the entire family. Further, a large portion of the Donation Land pioneers were concerned with providing a freehold for their children. A portion of the Donation Land pioneers took an active role in the development of Salem as a commercial center. Recipients of oregon land under the terms of the 
Donation Land Law held a commanding position in the development of the society and economy. The Donation Act granted over 2.5 million acres to just under 7500 settlers. The claims encompassed most of the fertile valleys of western oregon. The settlers were in control of the land in oregon. Their position allowed them to shape oregon for many years. ${ }^{13}$ Their creations are examined herein. 
The Farmers Song

Away to your fields and gardens away, No longer your rural employment delay;

Since to vision of gold doth so many delude, May it be our enjoyment to furnish them food. Though miners may say "let the cabbages rot!"

And that work in the gardens they surely will not:

For the gossamer fabrics we have no desire-

Tis said "a burned child has dread for the fire."

Come take up the spade and the rake and the hoe,

For it is by industry that "cabbages" grow;

Nor yet can the patch of potatoes be spared

For gold cannot buy them unless they are reared.

No rifles we want, nor revolvers we need,

Whilst plowing our soil or sowing our seed;

And if porkers assail us we'll call for the dog

And, I tell you, old Jowler is death on a hog.

While the spectator editor gives us applause,

And lends us his aid in support of our cause,

We will not forget that he every thing knows, -

But we'll send him a "big Turnip" as soon as it grows.

Could people more generally taste the enjoyment,

That may be obtained by rural employment.

From their airy built castles they quickly would sally,

For "turn-ups of gold" in their own pleasant valley.

And now brother farmers, for very good reason,

Let us husband the time with regard to the season,

And lay up a store, the poor miners to feed,

When they shall return, disappointed indeed;

Yes, when they exhibit their rueful faces,

And tell their heart-rending tales of distresses,

We will kindly assist them, when things happen thus,

Just as we would have them do unto us.

And perhaps it were well if we all could remember,

That in July, or August, or may be september,

When good Mr. Easy returns from the mines,

And to his surprise and astonishment finds,

our gardens all loaded with peas and potatoes,

with "cabbages," onions, and bouncing tomatoes,

And see what a Ninny he was thus to roam,

"Great Scott" how he'll wish that he had staid at home.

$$
\text { O.P.Q. }
$$

Yamhill, April 3, 1851 
The nature of westward migration is best characterized by the anecdote, allegedly from the early 1850s, that describes the character of the immigrants to oregon and California. According to the tale, at one of the crossroads on the western trail there was "a pile of gold-bearing quartz [that] marked the road to california; the other road had a sign bearing the words 'To Oregon'." Those who could read went on to oregon, the rest went to California. 1 settlers to oregon were drawn to the prospects of farming, and consciously avoided the accumulation of wealth within a capitalist market structure.

Settlers to oregon came to farm. They made a conscious decision not to go to the gold fields of California. This hearty breed of farmers had a image of themselves, as is indicated by the poem that introduces the chapter. In the "Farmers Song," which appeared in the oregon spectator in 1851, the oregon author drew a line between his neighbors and those who tried their luck in California. Oregon farmers knew that their chosen 
profession was the highest. It would be they who were present to assist the "ninny" who spent his time chasing "visions of gold". Oregon farmers saw themselves as hard working, and they enjoyed the labor of rural life. Further, the call to "husband the time with regard to the season" indicates that farmers, as a class, were aware that their calling was a high one. They were not bound or subservient, except to God. The poem evokes these benevolent yeomen's conviction that they were not alone in their attempt to provide for the needs of all in society, including their fellow "brothers" in the mines. Most importantly, the author conveys the impression that commercial agriculture is to be avoided. Below, this aspect of Oregon society will be explored in depth, to determine the exact complexion of rural oregon society and the role of markets in its development.

A vital relationship existed between man and land on the Oregon frontier. At the foundation of this relationship is the agrarian myth: the idea that man would be cleansed by his closeness to the soil, that by sowing and reaping the bounty of the land, man was somehow closer to God. This myth is based on the belief that the close relationship between man and earth, a relationship that provides man with food, clothing and shelter, and enables him to survive. 2 The most abundant resource in Oregon in 1850 was land. In fact, land was 
the primary influence behind the settlers' decision to migrate. Settlers were drawn by the prospect of claiming one square mile of land. The society that developed in oregon drew its strength from the land.

The first generation of oregon settlers, those attracted to the land, brought with them the institution of the family, as it had developed in the Middle west. Migration was not new to these pioneers, for their parents had likely moved to the Middle west from points east. The culture that developed was influenced by nature and the family. Nature provided a cycle that provided the lives of the farmers with regularity and order. Tasks were performed with seasonal regularity. Continuity existed because farmers did the same work their families had been doing for generations. Success hinged on crops, which in turn depended upon favorable conditions of nature. The family was a buttress against the forces of nature. It provided security. Tasks were appointed to each family member, identifying their place in the domestic circle. Division of labor by gender was the rule. Men engaged in the outdoor and public aspects of life, while women were in charge of the private and noncompetitive world. ${ }^{3}$ The family was the main economic unit as well. Work centered on family lines. Men and boys worked the crops and animals. Women and girls worked in the house, producing necessary items and preparing meals. The family 
was the beneficiary of all activities. The subsistence needs of the family were deemed of greater importance than material wealth derived from engaging in large-scale commercial agriculture. The farmers from the Mississippi and ohio River Valleys had witnessed the collapse of commercial agriculture in the $1830 \mathrm{~s}$, with an attendant loss of land. The Iure of free land in oregon, coupled with the loss of faith in commercial establishments and a lack of cities, acted to both push and pull farmers to Oregon. The uncertainty of living in a new environment was overcome by the prospect of a fresh start. Settlers established a new society and economy of their own making, while retaining a familiar culture. Their legacy would persist. 4

The oregon Donation Land Act attracted a Iike-minded populace to oregon. The prospect of possessing a large tract of land by occupancy motivated settlement of oregon. Settlers benefited from the land in numerous ways. Melvin C. Jacobs identified one of the motives for the journey as the improvement of one's condition. This was accomplished by acquiring claim to land under the provisions of the liberal Donation Land Act. Jacobs further identified the class of people that were able to make the trip as those who had established a permanent home in the Midwest, and upon the sale of their property, could afford to provision an expedition to oregon. In 
this sense, Oregon land attracted a class of individuals, who, as farmers on large tracts of land were presented with the prospect of creating an economy in which they could prosper. 5

In order to understand the implications of the Donation Land Law, one must look at the various ways in which free land could enhance "one's condition". First, and most obviously, the land could be transformed into a valuable agricultural resource. In fact, "purchase" of the claim was contingent upon occupation and improvement of the land. Improvements most often included a residential structure and some land under cultivation. The second way that land could enhance one's condition was the sale of a portion of the tract, while the family retained a portion for its livelihood. A third possibility was alienation of the entire claim after four years residence. The income from the sale was then used to move to other parts and establish a livelihood there. The land was definitely a valuable resource.

Historians of the Pacific Northwest have studied the Donation Land Law in varying degrees. Many have criticized the law, claiming that the size of the claims discouraged interaction among neighbors. Hubert Howe Bancroft argued that they "encouraged slothfulness, rapacity, and stirred hopes for an unearned increment....6 Bancroft's indictment of the law overlooked the social 
and economic creations of the recipients. This thesis examines those creations and offers an alternative explanation based upon the case study of a neighborhood that bordered the city of salem.

The life of Fabritus R. Smith, Oregon pioneer and farmer, is outlined in an account book he compiled from 1854 to 1858. An emigrant of 1846 , he settled his land claim in January 1847, under the provisions of the oregon Provisional Government. Consistent with the provisions of that government's organic Act, Smith resided upon and made improvements upon the land. His claim, 625 acres, was located on the rolling hills just south of salem at Section 3, Township 8 South, Range 3 west and section 34, Township 7 south, Range 3 west. It was later conferred upon him by the Donation Act of 1850. Thus Smith came to reside approximately $11 / 2$ miles south of the oregon Institute in salem, oregon Territory.

Within a radius of six miles from Smith's farm was the neighborhood, the neighbors with whom he lived most closely. This neighborhood contained his closest friends, such as Joseph waldo, with whom he traveled overland. 7 In this neighborhood also resided the family of Smith's first wife, Vergelia Pringle, whom he met and married in oregon. William Bowen, in The willamette Valley, focuses upon this neighborhood concept when writing that the settlement of Oregon's Willamette Valley amounted 
to a series of neighborhoods. These neighborhoods were a union of persons with similar backgrounds who strengthened the existing social order. Further, Bowen argues that these homogeneous confederations of households were vital for human survival in the wilderness. The neighborhood that developed on the rolling hills south of Salem served to promote the interests of all inhabitants--and their primary interest was yearly subsistence.

The cycle of Smith's yearly activities were consistent with subsistence farming. The activities of the Smith household were geared toward material survival. The Smith farm was not self-sufficient, able to produce everything the family needed to survive, but neither did Smith engage in large scale market transactions to fill his family's needs. These he met through direct exchange with other households in his neighborhood. Reciprocal exchange facilitated the transfer of surplus goods and labor throughout the neighborhood without the development of a market economy. ${ }^{8}$ Smith spent the majority of his time working his farm. In addition, he worked for his neighbors, and in turn, they worked for him. Further, surplus goods were exchanged in order to meet the specific needs of each family. Smith's family in 1854 was small. The conjugal unit had produced one son. A daughter was on the way. 
Throughout the years 1854 and 1855, Smith's agricultural activities were seasonal. He plowed, sowed, and harrowed in the spring and fall, while in the summer, he harvested and threshed his crops in preparation for consumption. The products of his labors included wheat, oats and timothy, a grass that was grown for livestock feed. He also kept a garden, which was worked in the spring. Further, he planted fruit trees with the same seasonal regularity. He made no mention of picking fruit until four years later, which indicates that his trees needed time to mature. The same seasonal pattern regulated reciprocal labor exchange.

Other activities related to the operation of the farm were the work of the winter months. The most notable of these was fencing, which involved the making of rails and posts from lumber that was cleared away to make cultivated land. Smith made no mention of clearing land in the years under examination. This task was performed in the years immediately following occupation. Cleared land was used for the dwelling site and cultivation. The procuring of meat was the work of the winter months. Slaughtering and butchering, as well as hunting, were activities that took place only in winter. Butchered hogs were smoke cured for use throughout the year. Reference was made to killing other animals, but only during the winter months. 
This trend held true with Smith's neighbors as well. Eleven different times Smith referred to helping a neighbor kill animals in 1854, eight of which were in January and February, the remaining three at the end of that year. The only time smith received assistance in slaughtering was in February. Fresh meat was scarce in Smith's family's diet. Likely, he purchased fresh meat in the summer months. In 1858, for example, Smith purchased meat in July

on the Smith farm were a number of different animals. Their care was a year round activity. Horses, hogs, cattle, and sheep were the animals most noted by Smith in his account book. Even though smith spent time building fences, he spent more time herding, driving, and looking for stray animals. The fences were around cultivated land, which served to keep out animals that ran at large and fed on the uncultivated grasslands. Animals were an integral part of the Smith farm. They provided a source of income, both from their products, such as wool, and from their live sale. ${ }^{9}$

Each type of crop and livestock contributed to Smith's, and other farmers', agricultural base. Farmers, out of necessity, did not specialize in one particular crop or type of livestock. Rather, they practiced diversification to produce a subsistence level of production. Farmers' production addressed a social need. 
Their production was based upon the needs of the family and neighborhood. The early oregon historian, H. O. Lang, wrote in 1885 that "... the cultivation of a variety of crops, or as it is called, diversified farming is in the opinion of the practical man, the surest road to independence, and has already been carried out in a notable scale throughout the valley, although the future gives promise of better results." 10

Smith hauled wood, rails, grain and straw an average of one day per week throughout the year. Even after the deepest snow of the year, Smith hauled wood with his sleigh. Examination of Smith's daily activities indicates that he, and other farmers, were busy year round in their attempt to provide a subsistence for their households. other of Smith's daily activities contributed to the interdependence of the neighborhood. He visited various neighbors approximately twice a month. These visits were social calls for the most part and promoted familiarity and fellowship. Bonds between neighbors were also established through attendance at church services. Smith's neighborhood contained a large Methodist Episcopal population. In addition, he traveled to the territorial legislature, served as a trustee of Willamette University, and served as a county juror in 1855 .

Such were the daily activities of the individual farmer. The Smith neighborhood was made up of several 
households. Together, these households were capable of meeting their subsistence needs without a market economy. Interdependence among neighbors in a given locale, in this case Smith's neighborhood, created a community that served to ensure survival of its inhabitants.

In 1855, in addition to agricultural duties, Smith spent the winter months working on his new house, while his summer was spent building a new barn. Construction projects of this magnitude required the manpower of several of Smith's neighbors. In January, different neighbors helped with heavy tasks in the completion of his home, and in June he had a barn raising. Temporary labor pools, such as the ones formed to help Smith, became important facets of community development. As circumstances dictated, an individual's need for labor could be filled, or they could provide labor for a neighbor. Smith's actions exemplify this very point. During 1854 and 1855, he was involved in twelve different barn raisings for various neighbors. In this and other ways, labor pooling accomplished large tasks while binding those involved in an interdependent community.

Each pioneer household on the frontier had something to give the neighborhood. Smith was no exception. He hauled for his neighbors once a month on average. He also performed various agricultural activities with seasonal regularity. Some of Smith's neighbors were 
tradesmen. Joseph Watt was a cabinetmaker. Watt provided Smith with his services in the completion of his house. Smith's father-in-law, Virgil pringle, was a mason. Pringle worked frequently in the winter of 1853 making chimneys for his neighbors. 11 Each of Smith's fellow Donation Land Claim recipients were farmers, and each had a secondary occupation that was vital to the development of their community.

Cooperation was an important aspect of neighborhood relations. Smith helped his neighbors once a week on average in 1854, and slightly less in 1855 when he was receiving help. He received help approximately once a month, most frequently from Albro Pringle, his brother-in-law. The month of August 1854, provides a good example of intracommunity labor exchange, with no monetary transactions. During harvest season, Smith helped his neighbor Abijah Carey with two days of threshing, and his neighbor Joseph Waldo with other work. On the other side of the balance, he received help harvesting from Joseph Smith and Octavius Pringle. ${ }^{12}$ Neighbors and kin exchanged work for each other as needed, and as they were available, according to a sense of community, rather than a desire for wages. In oregon, in the decade of the 1850s, households were unable to produce the necessary labor force for all aspects of subsistence. Reciprocal exchange, outside of market structures, filled this need. 
Labor, as a medium of exchange, was accounted for by Smith. Smith's account book contains entries accounting for his labor, as well labor he received. Notably, Smith never recorded a debt of labor nor any obligation to perform labor. The system of labor exchange was apparently voluntary. Labor was frequently exchanged, and in face-to-face transactions, imbalances were reckoned. The accounts Smith compiled served as a record of his duties and obligations, as well as those owed to him. ${ }^{13}$ The economic activity indicated in Smith's account book brings to light the nature of the economy in oregon. Labor was not a commodity that settlers bought and sold. Farmers acquired commodities, such as sugar, salt, and coffee, and services, such as milling, through barter or a crude monetary system in which the passing of paper and notes served as a system of credit. Smith's activity in the neighborhood economy was quite limited. He averaged only one barter or personal monetary transaction per month in these early years.

These transactions were made between Smith and neighbors in a way unfamiliar to the twentieth century. Each transaction was noted in Smith's account book. In the absence of currency backed by a bank or other financial institution, there were notes issued by a farmer and backed by the word of the issuer. These notes were written against the assets of the issuer, and served as a form 
of currency. Notes served to secure obligations between individuals. Defaulters were taken to court in the territorial legal system. Once the obligation was satisfied, the note was returned to the issuer. The note could be called-in, or exchanged by the holder. For example, in 1854 Smith held notes issued to John Hughes from various individuals. These notes were returned to Hughes once the obligation was satisfied. The face-to-face nature of the transactions tended to strengthen community interdependence.

Farmers "purchased" goods and services in a different manner. They used barter exchange, where goods and services were exchanged directly. Smith used barter more frequently than personal paper as noted in his account book. An example from May 27, 1854, will clarify this policy. On this day, smith noted that he "went to town settled with Mr. Cross sold blue." Cross was a butcher in salem. The sale of blue, some breed of livestock, served as tender. What the notation does not tell us is whether or not cross purchased the animal, or whether money changed hands in the transaction. Most likely, Cross took possession of the animal as settlement of his account with Smith. The barter system of exchange was direct. In this system of exchange, one good was exchanged for another.

Most of Smith's livelihood came from his own labor, 
with some assistance from neighbors and kin. The crops he produced and the livestock he raised were used both for immediate consumption, and to procure goods and services he and his family were unable to produce. Thus, Smith's household produced the food it needed, and with the help of neighbors generated a labor force capable of meeting subsistence needs.

Smith's account book for 1856 and 1858 indicate that a system of credit evolved throughout the community. Smith showed payments on accounts to merchants for such goods as groceries, hardware, boots and shoes, and sewing items. He showed paid-outs to individuals from his neighborhood, although he did not describe the nature of the transactions. Only in May of 1858 did he indicate a payment for work received. On the other side of the ledger, Smith received cash from some neighbors, but never for work performed. He received cash from the sale of goods produced on his farm, mostly wool and animals on the hoof. Further, he sold fruit, posts, and wheat in 1858. He made no mention of any such transactions in 1856 or before.

The preceding analysis indicates that a market--in modest proportions--did exist in Salem in the early $1850 \mathrm{~s}$. However, it was not a market that functioned solely upon a basis of cash for the acquisition of goods. Smith's involvement in the market was limited to acquiring goods 
that his household and neighborhood did not produce. Neither Smith nor his neighbors produced for the market. Rather, the market siphoned off surplus production. Necessary items that were not produced on the Smith farm were acquired on local markets through direct exchange of surplus production.

Smith's economic activities did not take him far from home. He went to salem, possibly a four hour round-trip, every other week. He did not specify his business on each trip to town. However, where he indicated what he was doing, about one-third of the time he engaged in some form of exchange. These transactions included a December 1854 trip where he "carried beef to town and fetch [sic] grist." In this barter exchange no cash changed hands. Further, he traveled to Portland once in 1855 and 1858, and to oregon City once in 1854. During his 1858 trip to Portland, Smith spent "cash paid for articles bought at Portland [\$] 62.66," and "Received cash for trip to Portland [\$] 20.00."14 He did not identify the articles purchased, or the source of the income. The portland exchange required the use of cash, because Smith did not haul produce to be used for barter. An important distinction must be made here between these transactions. First, fetching grist was a transaction in which smith personally knew the other party. on the contrary, the trip to Portland involved a stranger 
outside Smith's neighborhood. In the first transaction it appears that he used the beef as barter. In the second, away from his neighborhood, he was forced to use cash. The distinction between these transactions was Smith's familiarity with the second party. The face-to-face nature of the household economy in salem was contingent upon familiarity. In turn, in Portland, Smith used cash were he was unknown and did not have access to other means. Smith's transactions indicate that a market existed for agricultural products. His activity within the market served his family's needs.

Smith's account book indicates that he did not look forward to large-scale commerce. That other oregon farmers similarly resisted market opportunities is evident in the oregonian in the 1850s. Wheat shortages in the spring and summer of 1852 were the result of the inadequacies of the 1851 crop. Editor Thomas Dryer predicted that the supply of wheat on hand, together with the new crop, would be scarcely sufficient to fill the expected demand. Faced with this shortage, Dryer heartily encouraged all farmers "to redouble his energies as he is certain of a liberal reward for his labor." He continued:

We would therefore urge upon the farmers of oregon to the importance of at once putting under fence and cultivation every acre of land you possibly can. ....Every acre of land cultivated upon your large farms, not only pays you well for your labor, seed, \&c, but it greatly 
increases the value of your farms apd adds to

the general wealth of the country.

That farmers did not respond to the editor's pleas is evident in a future number of the oregonian: At the San Francisco market, Dryer declared,

the products of oregon are in demand at high figures if our farmers could be induced to put in crops and attend to them with the same persevering industry that the farmers of the Atlantic states are in the habit of doing.... 16

Not even Dryer's insults motivated oregon farmers to increase significantly their production for markets. In fact, as late as April 1858, the situation had deteriorated to the point that butter was being shipped to Portland. ${ }^{17}$ The industry of willamette valley farmers was questioned by local merchants when they failed to take advantage of the available markets. The situation that existed in Oregon was indicative of farmers' desire to produce for their household needs rather than for capital accumulation.

The often quoted letter of oregon farmer Thomas Kendall offers insight into the question of industry. One oregon farmer, commenting on the nature of farming in Oregon stated that "[f]ew of our farmers are yet prepared to cultivate the earth in such a way as to ensure the highest results which the land is susceptible of being made to Yield." He noted that crops were put in with 
little preparation while "attempt[ing] nothing more than to raise a sufficiency for their own use...."18 oregon farmers had their own say about the importance of their occupation as farmers.

Agriculture undoubtedly demands our first care; because its products, in the aggregate, are not only of greater value than those of any other branch of industry, but greater than all other together; and because it is not merely conducive to the health of society, the health of trade and commerce, but essential to our very existence.

The market activities of farmers on the oregon rural frontier indicate that providing for the family was their primary concern. This was accomplished with help from the rest of the community. Each household provided something necessary for the community, whether it was agricultural labor, or goods or services. Households developed an interdependence. Labor pools, secondary occupations, labor exchange, and economic interdependence all served to bind the households into a community. Community labor also served as a social event. Barn raisings, which required a large labor force, were times for friendship as well as work. Further, agricultural labor requiring a large labor force, such as threshings, were also social events. Sarah Hunt Steeves remembered helping the neighborhood women prepare meals for threshing crews in the early days of oregon. She wrote that "The 
visiting neighbors, both men and women, were made welcome, as it was sort of a gala time." 20

Cooperation among farmers manifested itself in another way: voluntary associations. Agricultural societies were the most publicized voluntary associations. The farmers of Yamhill county were the first in the Territory to organize a society. The leading newspapers of the Territory presented a favorable attitude toward the organization of an agricultural society. Asahel Bush, editor of the oregon Statesman, wrote of the october 4 , 1853 meeting: "We are pleased to notice that the initial steps toward the formation of an agricultural association have been taken by the farmers of Yamhill county. and we trust their movement will be seconded by their brethren in other counties." 21 The farmers of Marion county organized themselves similarly, with the adoption of a constitution at a meeting held on May $13,1854$.

The organization of agricultural societies spread from the seed planted in Yamhill County. Eventually, a state Agricultural society was organized. The purpose of the societies was greater than the annual agricultural fairs that each sponsored. As noted in the statesman:

There is no part of the world where agricultural... societies are more necessary.... The experience and experiments of 'the states are of little or no service here. Our climate, seasons and soil differ.... New experiments must be tried, and new modes adopted. ....[E]very 
thing is to be learned anew. 22

Among farmers, the importance of the societies was the exchange of information and new practices. The statesman writer evinces the peculiarities that made oregon unique.

As late as 1859 the oregon Farmer was attempting to boost membership in agricultural societies by espousing the value of group solidarity. Farmers were called upon to "recognize the common interests that exist among the cultivators of the soil," and to "unite as a class in the State." Agricultural societies were designed to remedy that situation by encouraging farmers to "contribute whatever each can" to the advancement of agriculture in Oregon. "The pursuit of agriculture is not self-remunerative alone; but the exemplary farmer becomes a teacher by example which becomes a kind of beacon light for a whole neighborhood." 23 Agricultural societies added to the life of oregon farmers by providing a unifying body where experiments were tried, and successes were emulated. Agricultural societies contributed as much to the interdependence among households in the community, as to the triumph of commercial agriculture. oregon's pioneer settlers were conservative, and their conservatism appears in the type of society they built. The farmers migrated to oregon in family units, and single men married soon after arrival if they could find a bride. The labor of the farm was carried out along 
familial lines, and all pitched in to help their neighbors, not thinking of monetary remuneration. The oregon farmers' self-removal from commercial agriculture exemplified their conservatism. Each facet of the newly developed society was forged to benefit the family farm. Community labor served each household and personal accumulation of wealth was not sought for individual advancement. Even the direct system of exchange functioned without third party intervention. The fact that neighbor helped neighbor is evident in the development of county and state agricultural societies. Even the social aspects of the community were developed with the family in mind. In short, the daily activities of the first generation of farmers in oregon had as their primary objective the advancement of the institution of the family. 
CHAPTER II

HOUSEHOLDS: THE FOUNDATION OF THE ECONOMY

On the Oregon frontier, the community that developed differed in distinctive ways from the older settled areas of the East. The area south of Salem examined here developed a sense of community based on fulfilling the needs of the family household. In the first years of settlement--before 1860--each household relied on the cooperation of neighbors who, in turn, provided assistance to their fellow pioneers when in need. In this respect Oregon differed most markedly from the community building experience of the Midwest, where communities were united by commercial interests. 1

Changes were under way in the community as the decade of the $1850 \mathrm{~s}$ closed. The community of nuclear family households that developed to augment subsistence was giving way to lineal families working for their own needs. Further, some Donation Land pioneers were removing their families from the neighborhood to tend other ventures. As the sons and daughters of the Willamette Valley pioneers began to mature and leave the family home, the household nature of the economy was subject to the demand that 
pioneer parents provide opportunities for their children. Children who settled near their parents strengthened the line between generations. Other settlers disposed of their families' land claims and moved on to establish themselves elsewhere. Still other settlers moved into Salem and helped develop a commercial center. These trends are apparent through an examination of the United States census from 1850 to 1880 , and the 1853 and 1895 censuses from Marion County. Analysis here focuses on persistence rates, as an indication whether the household head was satisfied (or not) with his position in society, and the age and sex-characteristics of the neighborhood, for the insight they give into the nature of the household and the relative position of the second generation. Persistence rates and age-sex characteristics provide evidence of the families' ability or willingness to establish children near them, and strengthen the lineal family structure. These trends illustrate the nature of the nuclear family structure of the 1850 s and the lineal family structure that emerged in the 1860 s and beyond. oregon settlers shared many characteristics. They tended to be farmers who were accustomed to moving, having lived at least $a$ while in the Midwest. They were relatively young and family oriented. Further, single men comprised a significant percentage of the overall migration. In the process of settlement, the immigrants 
to this region settled near kin, if in the area, or people with similar backgrounds. The settlement patterns of the oregon pioneers tended to strengthen existing social patterns. When the first settlers arrived, all that they had was what they had carried with them. The family was the primary social unit. Their very survival depended upon locating near family, friends, and like-minded people, and then developing a network of relationships that insured their economic well-being. Reliance upon neighbors was imperative, as extended families were rare in oregon during the first decades of settlement. The neighborhood changed over time. First, the lineal family developed and replaced the neighborhood as a primary force organizing local society. Second, settlers left the neighborhood for points both far and near. Third, salem grew as a commercial center. Certain aspects of the neighborhood persisted despite the changes. The settlers in Fabritus Smith's neighborhood were no exception to these general trends. In order to obtain a clearer understanding of the community it is necessary to examine a representative set of the households. In this study, smith's neighborhood is limited to the fifty households with which he interacted in 1854-1855.2 Each of these households was located within a four township quadrant comprising the present site of Salem, Oregon. These fifty households represent roughly one-third of the households in the geographic vicinity. 
Smith's household was near the geographic center of the area. Those with whom he dealt decreased as one traveled away from Smith's household: technology and natural barriers in large part determined the web of households within Smith's neighborhood.

oregon society was comprised of hundreds of such neighborhoods in the early years of settlement. Each neighborhood shared characteristics such as migratory patterns, family size, and the development of relationships that strengthened the economy. Smith's neighborhood brings to light these characteristics and indicates the development of a household based community in this geographical region was not an isolated occurrence, but rather representative of the oregon rural frontier. Bowen's study of the settlement patterns of the willamette valley identifies the development of neighborhoods. 3

In the early years of settlement the neighborhood was dominated by nuclear family households. This is due in large part to the Donation Land Law that stipulated that a couple could hold twice as much land as a single man. In order to claim a square mile tract under the Act, a couple had to stake their claim by December 1 , 1850. Hence the law exerted a great amount of influence over the social structure that developed in the oregon. There were a few single male households, and as a rule single men married soon after arriving in oregon. The 
mean date of these unions indicates the land law's influence on settlement.

Smith's neighborhood was comprised of fifty households. Thirty-two arrived before 1850, and claimed land under the Donation Law. The remaining eighteen arrived before 1853. Thirteen of these later arrivals established themselves in Salem and purchased land. The remaining five received Donation Lands. Of the fifty men, half migrated as bachelors.

Thirty-two of the fifty men who ultimately made up Smith's neighborhood were present in Marion county in 1850. The total population of these Donation Land Claim recipients in 1850 was 163 men, women, and children. ${ }^{4}$ The male heads of the households ranged in age from twenty-three to fifty-eight. Their average age was forty. Analysis of the age and sex characteristics found in the 1850 census brings to light the stage at which Smith's neighbors were in the life-cycle. ${ }^{5}$ The population of the neighborhood was disproportionately split between men and women, in favor of men. of the 163 residents, forty-five (278) were men over the age of 18 . Of these men, twenty-eight (62\%) were married, three (7\%) were bachelors, nine (20\%) were unmarried sons (or otherwise related), and five (11\%) were engaged in a occupation boarding with a family.

These figures underscore the centrality of the family 
to this neighborhood. This is further supported by the fact that children outnumbered adults. Fifty-four percent of the population was under eighteen years. Seventy-five of the first residents were over the age of 18 , the remaining eighty-eight were children. These eighty-eight children resided in twenty-eight households, giving an average of 3.1 children per family. The fertility ratio, the number of children under ten for every married woman, was two.

William Bowen's study of settlement patterns in the Willamette Valley found that unattached men were more likely to be found in the scattered urban areas in the northern part of the valley and that large families dominated the landscape further south. ${ }^{6}$ The demographic breakdown of Smith's neighborhood is consistent with Bowen's findings. Generally speaking, nuclear families dominated the social structure of the neighborhood. The settlers with whom smith dealt during the first half of the of the 1850s were heads of households. This neighborhood consisted of nuclear family households with an average of just over five occupants. The vast majority of the households, twenty-nine (908), did not have unattached men or women engaged in an occupation. Despite the influx of a number of newcomers between 1850 and 1853, the social structure of the neighborhood did not shift. The nuclear family retained its dominant 
position. Like-minded people were attracted to the neighborhood. By 1853, the remaining eighteen heads of households arrived in Marion county, bringing the population to 234.7 of the fifty households in Smith's neighborhood, thirty-seven staked and received land claims from the United states Government. The remaining thirteen either purchased a farm in the neighborhood or practiced a business or profession in salem proper.

The 1853 Marion County census does not break the population down according to age. However, such a break-down is possible when the information from the 1853 census is compared with the United states censuses from 1850 and 1860. The age of each occupant in 1853 is determined by using the age data in the United states enumerations and figuring the birth date for each male and female present in 1853. The comparison shows a population very similar to the findings from 1850. When the population of 234 is broken-down into life-cycle stages, age-sex and fertility ratios vary little from the 1850 findings. New arrivals between 1850 and 1853 had very little impact upon the existing social structure.8 Breaking the 1853 population down according to age and sex reveals that there were 67 males over the age of eighteen and only 46 females in the same age group. This yields a sex ratio of $1.4: 1$. Of the fifty households studied in the 1853 Marion County census, thirty-eight 
contained married men. In these thirty-eight households there were ten unmarried sons over the age of eighteen and seven male borders. Thus, 82 percent of the adult male population lived in households with a conjugal unit. Only twelve (18\%) were single men in their own households. On the surface, this break-down shows a fairly equal distribution of the population in the various life-cycle stages; however this was not the case. of the fifty households only thirty-eight contained married men in 1853. This left 29 adult, single men, and only eight adult women as yet unmarried. Therefore, the number of single men was more than three times the number of single women. This ratio is very much in tune with the findings of other Oregon historians. ${ }^{9}$

Females under the age of eighteen outnumbered males of the same age in this neighborhood in 1853. Of the 121 children, 70 were female and only 51 were male. The small number of male children is unexplainable. The small number of male children affected future labor power of the neighborhood. The number of male and female children between the ages of eleven and eighteen were evenly split. The difference comes in children under the age of ten, where females outnumbered males almost two to one. The fertility ratio remained at two children under ten for every married woman.

The youth of the region's settlers is also reflected 
by their migratory patterns. Oregon attracted farmers from the Middle west who could sell their farms to finance the journey across the continent. Another segment of the immigrants were single men who came recommended as worthy agricultural laborers from the Midwest. ${ }^{10}$ These two seemingly disparate groups proved to be common-minded. of the fifty households, marriage records are complete for forty-two. Of these, only six (15\%) of the couples met and married in the eastern United states. They were all married in the early 1830s. The men in these unions averaged 25 years at marriage; their wives were just over 20. These ages indicate a period of twenty years of farming that enabled them to amass the funds needed to finance emigration to oregon. of the remaining thirty-six (85\%), twelve couples (30\%) met and married in the middle portion of the United States. These marriages were recorded before 1838. Again, their average age at marriage, 25.1 and 19.6 respectively, allowed time to establish lives as farmers in the Midwest and provided the necessary money for the overland trip. ${ }^{11}$

The second group of immigrants, single men, reflect the remainder (558) of the neighborhood. These men married after arriving in oregon Territory. Fourteen (67\%) of these couples received Donation Land grants from the United States Government. Most (71\%) married between 1845 and 1848. The average age at first marriage was slightly 
higher for men, 27.8, and very low for women, 18.4 years. This difference indicates that single male immigrants married wives after settlement to obtain a larger land claim. Further, the age of the women in these unions illuminates the unavailability of unmarried women, as identified above. The remaining seven (33\%) married in the 1850s. The men in this group were older at the time of their marriage, on average over thirty, and the availability of young single women was low; their average age at marriage was around twenty years. ${ }^{12}$

By 1854, the Smith neighborhood's social structure was in place. The family was dominant. Forty-five (908) of the households contained a conjugal unit. Children were present in forty-two (84\%) of the households. The ties that bound the neighborhood were strong. Persistence rates among these early settlers attest to this. Of the first thirty-two settlers in Smith's neighborhood--those who arrived and staked a claim before 1850--twenty-eight $(908)$ remained in the 1860 census. Over the twenty year period between 1850 and 1870 , twenty-three $(74 \%)$ of the earliest settlers in Smith's neighborhood persisted. Such a high rate of persistence is expected among Donation Land Claim recipients because of the command they had over the land. These early settlers had land adequate to their needs, and in the process of establishing their farms, forged ties that 
bound them to their neighbors. ${ }^{13}$

Among later arrivals and non-land claimants (the remaining eighteen households in the study), the persistence rate was $78 \%$ through 1860 , dropping to just over fifty percent by 1870 . This indicates that the ties established in the early years of settlement, coupled with the security of the family farm, tended to make permanence the logical choice among settlers receiving a land claim. This distinction is underscored in the different persistence rates that characterize thirty-seven Donation Land Claimants from the thirteen non-claimants. Twenty-six (70\%) of the former stayed for at least twenty years, while only seven (54\%) of the latter remained for twenty years. Despite the high rate for both groups, land had an effect on permanence.

Looking at the entire neighborhood, we find that the family status of an individual correlated with persistence. Of all fifty households, two-thirds of the unmarried household heads left Marion county before the 1860 census. Their reasons for leaving are unknown, but perhaps single men did not "fit in" to the household and familial nature of the neighborhood.

The pioneers' dramatic persistence rates reflect common experience. First, they shared a common background. The settler's migration and settlement patterns were common. Further, they shared protestantism as a religion. 
And finally, several of their numbers traveled in the same overland trains.

The settlers' migration and settlement patterns show how the overland experience strengthened the existing social structure. The residents of the neighborhood exemplify patterns that have been identified for all of oregon. 14 oregon settlers' westward migration is evidenced by examining the census records for all the settlers to Smith's neighborhood. Age and place of birth for all 165 residents of the neighborhood were derived from the 1850 census. Eighty-four (51\%) were born east of the Mississippi River in the 1810s and 1820s. Seventy-six (468) were born in the Western Border states of Iowa, Arkansas, and Missouri or Oregon Territory. Most of these were born before 1846. Five (3\%) were foreign born. The settlers slowly moved from the older settled areas of the East to the newer settled areas in the West. This trend is illustrated in one family's migration. Charles Craft was born in Pennsylvania in 1803, and his future wife was also born in Pennsylvania six years later. The two were married in that state in 1829, and in the same year their first child was born. They then moved to Virginia where two more children were born. The craft family is known to have moved to Missouri by 1843 when the birth of a daughter was recorded. Their last two children were born in oregon Territory before 1847 . 
The craft family migration exemplifies the pattern that is accepted for all of oregon. But why did they choose to settle near Fabritus Smith? Similar migration patterns do not provide motivation for settlement in Smith's neighborhood, but rather the common backdrop against which other factors emerge. The answer to the preceding question is many-dimensional. The first settler to this neighborhood was affiliated with the Methodist Mission. William Holden Willson was on the board of the Oregon Institute, and as agent for the property which comprised the entire townsite of Salem was empowered to sell town lots. 15 But the Methodist Church was just one of many factors that encouraged settlement.

In fact, Protestantism was the religion of the vast majority of the early settlers. The records of the First Methodist Episcopal Church of Salem reveals that eighteen (498) of the thirty-seven Donation Land pioneer household heads were listed in the church register. 16 of the remainder, seven (198) are known to have been members of the Protestant Episcopal Church. The religion of the remainder is unknown. Religion played a very strong role in the decision where to settle. 17

Another link in the network that bound the neighborhood together and encouraged settlement stems from the actual overland journey. The very earliest settlers, those who arrived in oregon before 1848, had 
a very high incidence of traveling in the same train. For instance, the William Helm family is known to have traveled overland in the same train as the Charles craft family. The fact that they settled near one another may be coincidence; however, it is more likely that they developed $a$ bond on the trek that carried over and influenced their settlement. Further, Fabritus Smith and Joseph Waldo emigrated in the same train as single men and settled adjoining lands. 18

The most significant single grouping of immigrants was the 1846 migration. Despite the fact that the train eventually split, no fewer than six future residents in Smith's neighborhood traveled in the same train. In the group that traveled the southern route to oregon, the Applegate cutoff, were Virgil K. Pringle and his family. Those who traveled the newly completed Barlow Road included the Abijah Carey family, James Townsend with his wife and daughter, Henry Croesynt (who married along the trail), and Turner crump. Friendships made on the trail continued through settlement and strengthened the neighborhood. 19

Further development of the ties that bound the neighborhood followed from marriages between settlers, and between offspring of settlers as well. Most notable was the marriage of Fabritus R. Smith to Vergelia Pringle, the eldest daughter of Virgil K. Pringle. other marriages involved the offspring of the settlers and single male 
settlers. The three grown daughter of charles craft each married pioneer settlers in the neighborhood. Each of these marriages contributed to the development of lineal families. Members of the second generation married five times, strengthening the connection between families. 20

Perhaps the factor that exerted the greatest influence in the decision to settle was the availability of good and productive land. Settlement in the southern willamette Valley followed a pattern. Peter G. Boag has shown that the timber-prairie margins were the first settled lands because these areas provided the necessary elements of survival to the earliest settlers. In Environment and Experience, Boag determined that settlers in the Calapooia Valley stayed in the foothills because there they could find good land, timber, and water. He generalized that this trend held true for the southern valley. 21

The settlement of Smith's neighborhood followed this pattern. The landscape south of Salem is dominated by foothills. Although Salem sits alongside the willamette River, and was the area settled first, the majority of settlers took to the hills. Salem's proximity to the river was necessary because the river was the main source of transportation and communication. of the thirty-seven Donation Land Claimants, only a half-dozen established themselves near the river or on prairie lands west of salem. 22 
The settlers in Smith's neighborhood arrived before 1854. Each household head was eligible for a Donation Land claim. Not all settlers desired a claim. Some settlers chose to settle in salem and practice a trade or profession. Both groups of settlers existed in community to meet their family's subsistence needs. Both groups of settlers were family oriented. Both groups had high persistence rates through 1860; however, the Donation Land pioneers remained in greater numbers. Despite similar experiences, intermarriage, and the development of a community, large amounts of land was apparently the strongest influence on those who remained. Recipients' disposition of their land claims underscores this conclusion.

The existing land records for each of the thirty-seven Donation Land Claim recipients in the study to were studied determine the size, the disposition, the amount of speculation engaged in, and the year of sale of the holdings. The study included deeds of sale, census material, probate records, and genealogical material compiled by the Oregon Genealogical Forum.

The size of the claims, as determined by date of arrival and marital status, varied from 160 acres to 640 acres. Twenty-six of the eventual thirty-seven claimants lived in Smith's neighborhood and had settled on land by December 1, 1850. They were then eligible for the 
full section claim. Ten received 320 acres. Of these two were single men who had come to oregon before December 1850. The remaining eight arrived later and, according to the law, received the smaller claim. A final single man settled after December 1850 and received a 160 acre claim. 23

Despite the varying size of the claims, the distribution of the original grants was quite equal throughout the portion of the population that was eligible. The construction of a Lorenz curve, used to show distribution of a good across a specified population, shows a distribution of acreage very near the line of perfect equality. The average holding was 498 acres. The Gini Index is a measure used to show the equality/inequality of a given set as it ranges from one (complete inequality) to zero (perfect equality). Used here to determine equality of land holdings, the index was a very low .14. However, comparing the distribution of acreage with the reported value of real-estate in the 1850 United States census reveals that not all land was valued equally (figure 1). The latter Lorenz curve shows a significantly higher rate of inequality in land value. The Gini Index of .405 reveals an unequal distribution of wealth based on reported real-estate values. The unequal distribution of real-estate values followed from the location and degree of improvement of the original 
o cumulative wealth/ assessed value

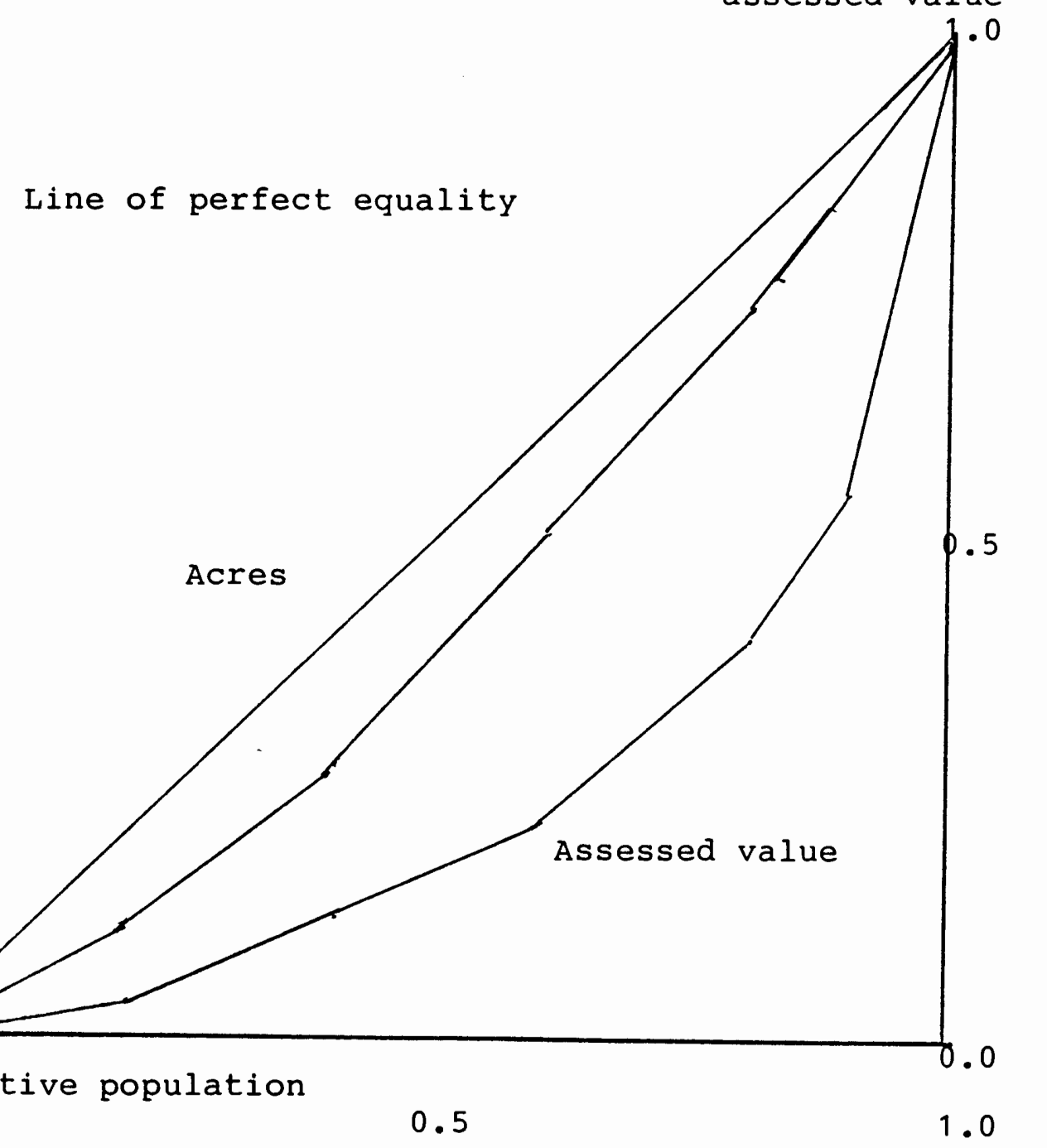

cumulative population 0.0

0.5 Figure 1. Lorenz curves showing inequality between acreage
granted by Donation Land Law and assessed value of real-estate 1850 . 
land claims. Since no known sales of land occurred between settlement and 1853, the size of holdings did not change. In fact, the law was amended in 1853 allowing alienation prior to receiving patent. 24

Location and improvements were the variables that influenced the value of real-estate prior to active sales. For example, the highest assessed value of real-estate was the holding of William H. Willson. The Willson claim was platted as the city of Salem, and estimated at $\$ 50,000$. Willson possessed one-third of the assessed land value in the neighborhood. The removal of willson from the analysis of value, yields a Gini Index of .10. Further, when the date of settlement is compared against the value of real-estate reported in the census, a direct correlation exists. Those settlers who arrived in oregon or settled prior to 1848 are the settlers with the highest real-estate values. 25 settlers who migrated before passage of the Donation Land Law were in a position to choose the highest valued lands.

By 1860 , the inequality of real-estate value had declined (compared to 1850 ). This is in part attributable to time: later arrivals were able by 1860 to improve their claims. In addition, the development of a real-estate market allowed these farmers to control their own real-estate values by selling marginal lands and replacing them with higher value lands. Most importantly, 
Willson passed away, and his holdings were sold. Farmers dissatisfied with their real-estate holdings removed. The greater equality reflected in the 1860 census was also the product of timing. The settlers who remained were present in Marion County at the very time when the land market began, and thus able to purchase land in varying amounts and in different locations. The laws of supply and demand that allowed relatively cheap purchases created a situation that brought higher returns when demand rose.

Plotting the Lorenz curve of real estate values for 1870 (using values from the 1870 census), reveals a return of more unequal distribution of real-estate values. The advantage enjoyed by the top 13.6 percent of the population (which held over 50 percent of the value of the real estate) represents that portion of the population that engaged most actively in the land market (figure 2).

Six (16\%) of the Donation Land pioneers sold their claims in their entirety between the year of settlement and 1859. Four of the six removed from the neighborhood. The remaining two moved to houses in Salem. Conversely, twenty did not sell any part of their claims during the same time period. The remaining nine sold minor parcels from their claims, but retained most of their original claims. 26 The majority of the settlers thus retained their stake in the neighborhood (as is also reflected 


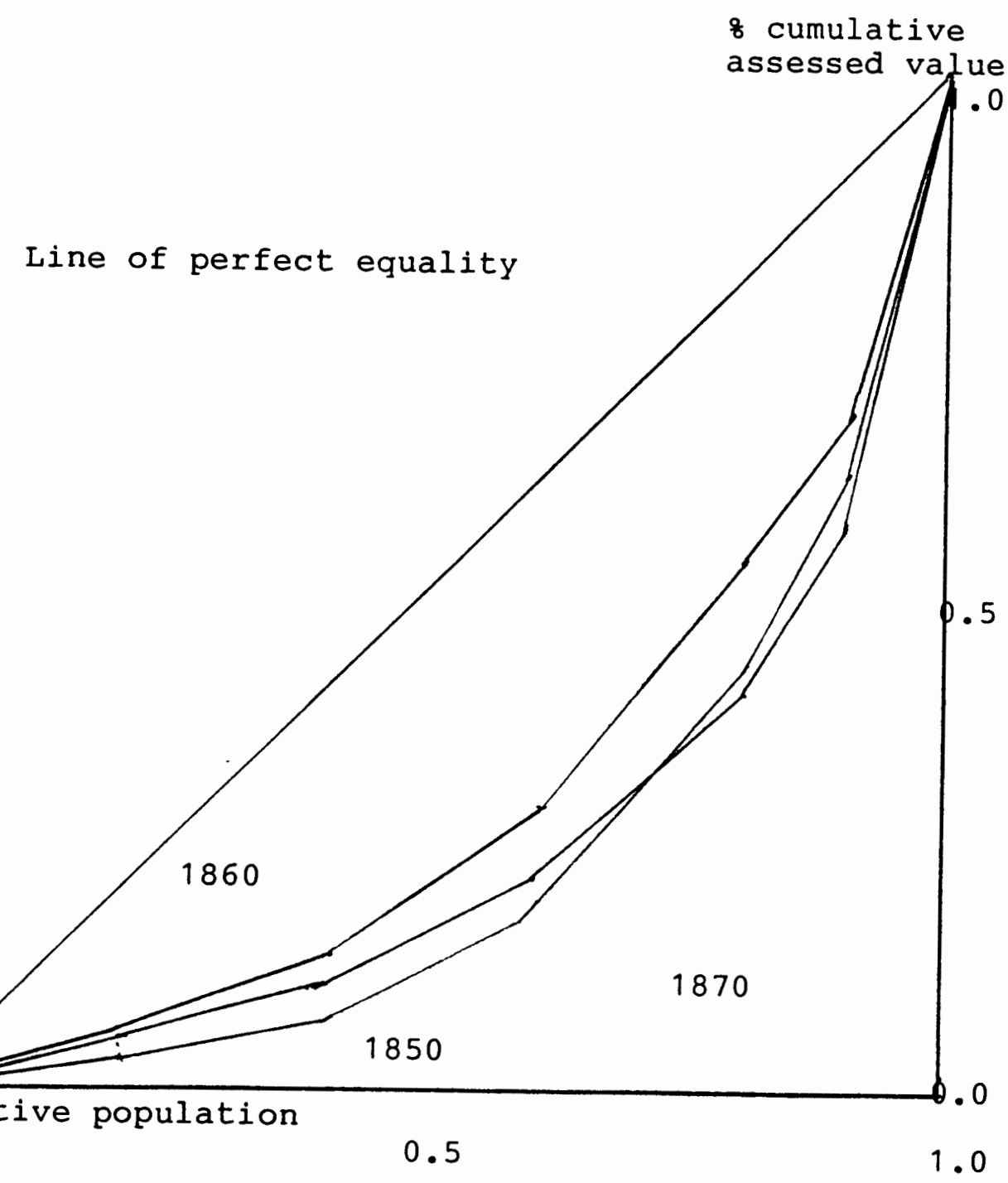

Figure 2. Lorenz curves showing distribution of assessed real-estate values $1850,1860,1870$. 
in the high rate of persistence). The average amount of land these settlers sold in the 1850 s was less than 175 acres. The price per acre ranged from a low of around $\$ 5.00$ to a high of near $\$ 25.00$. The majority of the sales carried a price of $\$ 10.00$ to $\$ 15.00$ per acre. This translated into relatively large sums of money, particularly given the fact that the land was originally free to the settler.

The precise reasons for these sales are unknown and open to conjecture. Perhaps a need arose for income to augment the family farm, or the pressure of population and scarce land created a favorable price for land. Some Donation Land pioneers sold their lands and used the money for other undertakings. None of the land was sold to the children of Donation Land settlers during the 1850s. In the period, 1860-1880, the same trend held. Forty-five percent of the Donation Land settlers remained to the latter date, as opposed to only 27 percent of Smith's neighbors who practiced a trade or possessed land through purchase. The lower persistence rates are indicative of greater changes that were taking place in society.

The decades of the 1860 s and 1870 s witnessed the beginnings of change. Nuclear family households continued to dominate society as they had in the 1850s. Forty-one of the fifty household heads remained to 1860 . In that 
year, thirty-seven of the households contained conjugal units, and the population of these households had grown from 163 (in 1850) to 273. The fertility ratio grew to 2.1 children for every married woman. The population growth was the result of natural increase and the increasing presence of boarders. The 35 boarders in 1860 was three and one-half times the number present in 1850.27 The 1870s continued the trend. By 1879, twenty of the thirty-seven Donation Land claimants had alienated their entire holdings, and another three had sold at least fifty percent of their Donation Land Claim. That is, for about half of Smith's neighbors (548), the Donation Land had become a commodity; they sold it to pursue ventures other than farming. For them the reciprocal community of the 1850 s had been one of necessity; few of these settlers retained connections.

The disposition of land by the Donation Land pioneers influenced the development of the lineal family. By 1883, only six of the original thirty-seven claimants survived and held any of their original claims. Sixteen of the original thirty-seven settlers had died and left land to their children. Fourteen settlers disposed of their entire land holdings and removed from Marion County accompanied by their families. The remaining settler was in the poorhouse.

The disposition of Donation Land was primarily by 
those pioneers who left Marion county, or by the administrators of the estates of those who had died. The Donation Land pioneers' disposition of land tended to weaken the community of the 1850 s and strengthen the lineal family strategy against commercial agriculture. Death and departure diminished the community connections. The deceased settlers provided land for their children through gift and inheritance. Those settlers who removed sold their land. The market for land existed, and Donation Land pioneers increasingly became involved in the market. Sales were strongest during the 1860 s, and reflect a larger pattern.

The decline of the community was accompanied by the increasing importance of Iineal families. In the 1860s, oregon was becoming a land-stratified society. One's position in society depended upon land holdings and can be statistically shown. The equality of land holdings among pioneers, as a result of the Donation Land Law, had begun to disappear. The Gini Index, used here to measure the equality of land value was .382 for the group in 1860. By 1870 the index was .485. Eighteen percent of the population of the study in 1860 held almost fifty percent of the real-estate value in the sample. By 1870, thirteen percent held half the cumulative wealth.

This is further shown by looking at the sons and daughters of the pioneers as they left the family home 
and started their own families. As sons and daughters matured and began to marry they were faced with the decision of where to settle. While many chose to move, of those who stayed the dominant position of the family remained. However, access to land defined opportunities available to the younger generation. Whether part of a larger family strategy geared to maintain parental control of land, or a desire by parents to accumulate the wealth that large land holdings provided, the majority of the second generation failed to gain adequate land to support a family in the neighborhood during the lifetime of their parents.

The second generation matured in waves. The first group of the second generation to mature, thirty-nine individuals born for the most part in the late 1830 s and early 1840s, show the nature of available opportunities. They came of age and left the family home during the $1860 \mathrm{~s}$, and they exhibited a fairly high rate of persistence. Four (10\%) died during this decade. Sixteen (418) of the 39 appeared in the 1870 census. Nineteen children (48\%) moved out of Marion County because they found opportunities elsewhere or were denied access to their parents' land. 28 of the sixteen, thirteen held land in 1870. Parents provided a freehold for nine of the children who came of age during the decade of the 1860s. Four children had direct access to land through the 
Donation Land act. Two daughters that were eighteen before 1860 married immigrants who practiced trades or professions in salem. One of the men in this group was living in the household of his sister's family and practicing a trade. Access to land, and the lineal family, encouraged persistence.

During the late 1850 s and 1860s, a shift occurred that made Oregon a land stratified society. For the second generation, kin and access to land were of great importance in deciding where to settle. However, the factor that was most likely to influence the decision to settle involved economic livelihood. The first thirty-nine of the second generation to mature illustrate this assertion. of the thirty-nine, sixteen (418) persisted. of the sixteen, thirteen (81\%) had land. These thirteen were farmers in 1870; obviously, land was necessary for their livelihood.

The fairly high rate of persistence among the first thirty-nine of the second generation to mature is testimony to their parents' willingness to provide for their eldest children. During the 1860s, discontented members of the neighborhood were leaving, and taking their families with them. When the entire family left Marion County the grown sons and daughters followed, and they were not considered in the calculation of persistence rates. A further possibility for the absence of some members of this 
generation stems from early death. A search of existing cemetery records did not confirm this, with the exception of four children that were born before 1842 and not present in 1860 . They represent 10 percent of the second generation population that matured by 1860 , and probably the extent of mortality among this group.

It is more likely that, following the pattern of five of the daughters that left the area to live with husbands from other Oregon counties, opportunities elsewhere attracted these young people. Opportunities unavailable in Marion County may have attracted sons as well. Apprenticeships, for example, might have been pursued outside of Marion County. However, of the nine men who were not present in 1860 , only two returned ten years later. These men were listed in 1870 census as farmers.

This first group to mature and move represent only seventeen percent of the actual second generation; therefore any definitive explanation of family strategy is premature. Further examination of the remainder of the second generation is necessary.

In 1870 , as expected, the entire population of the neighborhood exhibited characteristics of aging. The fertility ratio fell to 1 to 1 and death had claimed twelve percent of the original Donation Land pioneers. Thirty percent of the first household heads had left Marion 
County, and with them went thirty-eight children. of the remaining second generation, for the first time, children over the age of ten outnumbered their younger siblings. In fact, the number of young men and women leaving the parental dwelling, 80, was greater than the number of children remaining, 78. The average age of those out of the home in 1870 was 28.3 years. The remainder of the second generation exhibited a low persistence, relative to their parents and other rural societies. Of the entire second generation, just one-third remained in Marion County to 1895.29 The second generation's access to land during the lifetime of their parents, and lineal family connections, determined persistence. Of the eighty children who left the parental home, eighteen (228) received parental land, while nine (11\%) remained in the neighborhood to practice a trade or profession.

By 1880 , the effect of aging upon the first generation was even clearer. Death had claimed one-half of the original household heads. And the fertility ratio fell to less than one to one. In fact, no children were born to the first generation after 1876. The only births among the settler generation in the decade of the 1870 s were to those families living in Salem. The persistence rate from 1870 to 1880 for the surviving Donation Land population was 83 percent. 30 
The fertility ratio of the second generation was 1.5 to 1 . Seventy children (358) left with their parents. only twenty-seven (208) out of the remaining 135 children were in their own households and present in Marion County in 1880. Twenty-five (18\%) were still at home. Sixteen (11\%) are known to have died. That left sixty (22\%) who left Marion County to pursue opportunities. Fifty-two children of the Donation Land pioneers (38\%) remained to 1880. Adjusting for those who died, and those who left with families, 448 persisted.

By 1895 there were eleven survivors from the first generation, and six were found in the 1895 Marion County Census. Fifty-five percent of the survivors had persisted in Marion county. Four $(2 \%)$ children remained at home. Twenty-six (13\%) children were in their own households. 31

In order to determine why so many of the second generation chose to leave, it is necessary to determine the opportunities that were available to them in Marion County. The majority of the men who stayed became farmers, much as their fathers had been. Others practiced a trade. In this group there were two teamsters, two carpenters, a blacksmith, and a laborer. Also available were professional opportunities. For instance, one son became a lawyer, another, a minister. For the Donation Land pioneers to place their children, the resources of the family were necessary for preparation for the occupation 
or trade that was chosen. Since this decision involved the use of family resources, it must be viewed as a family decision.

The opportunities for women in oregon society were more limited. Most young women married farmers and attained the status of farmers' wives. Two single women in this study were listed in the 1870 census as dressmakers. 32

By 1880 , in the neighborhood, nuclear families working in community had been replaced by lineal families working for themselves to provide subsistence. The Donation Land pioneers' children exhibited a lower rate of persistence, relative to their parents, because they were denied access to parental land during their parents' lifetime. The decline of the community is attributable to two factors. Some pioneers left their original homes to pursue opportunities in salem and elsewhere. Further, the death of many pioneers had depleted the number of connections. The community's replacement by the lineal family coincided with changes within society. The decline of existing connections in community were replaced by the lineal family. 


\section{STEMMING THE TIDE: \\ The Generation That Time Forgot}

Oregon was peopled by the migration of families from the Midwest. The social structure that developed was that of the nuclear family. As the settler population aged and died, the sons and daughters of some pioneers remained in the neighborhood. Other grown children left Marion County, both with their families and to pursue opportunities elsewhere. The persisting second generation settlers retained remnants of the material life of their parents. As the second generation matured and started their own families, the lineal family replaced the community in the struggle for subsistence. Although not a drastic change (each family retained its nuclear household structure) the change was felt first among the older portion of the pioneer generation in the 1860s. This shift followed a logical progression for, given the centrality of nuclear families, as the children became adults the line between them and their parents continued. The Donation Land pioneers sought to establish their lineal family connections, as is shown by their practice of 
providing land to their children. The progression of time saw the lineal family supplant the community as a production unit. The community still existed as a social unit, but the lineal family was increasingly the productive unit. Reciprocal labor within the family replaced, increasingly, reciprocal labor between families.

The transition to a lineal family economic structure is evident in the family labor pattern that evolved in the 1860s, and in the land transfer strategies used by the first generation pioneers throughout their lives. In the early years of settlement, the neighborhood developed a community-based economy that was characterized by household production. The face-to-face nature of the economy was evident at the exchange level. The merchant knew the farmer, and credit was extended throughout the year in anticipation of the coming harvest. The widespread use of barter exchange signified the most notable aspect of the economy. The settlers established a crude, personal, monetary system. They exchanged goods in a local market that was not based solely upon cash. This situation existed for upwards of half a century, stemming the tide of change. Change came slowly. The community as a organized body of production changed. The economy of Smith's neighbors changed. The household mode of production changed, but remained intact. Despite these changes, Hamlin Smith, son of Fabritus Smith, lived 
much as his father had. As the younger Smith's generation approached midale-age, salem had grown into a commercial center. However, his generation could expect to live much as their fathers had. They accomplished this through the use of developed familial ties to organize production. Brother and brother-in-law worked side-by-side in the fields, while sisters-in-law prepared meals and other household goods. Other neighborhood households employed outside labor to augment family labor in providing subsistence. Commercial agriculture existed for those without lineal family ties.

Fabritus Smith's account books from 1863 to 1874 illustrate the nature of these changes. Similarly, Hamlin Smith's account books from 1894 and 1902 evidence the degree of change within society.

Not until the 1860 s did lineal families begin to supersede the community as an organizing institution in the Smith neighborhood. The United States census for 1860 lists 26 unattached men in the households of the Smith neighborhood working as farm laborers, apprentices, and other occupations. In addition, nine women worked as domestics and in other jobs. 1 Their presence was not new in the neighborhood, but none of those present in 1850 remained in the same household until 1860.2 The total number of unattached people residing with a family in 1860,35 , marked a 3508 increase since 1850. The use 
of non-family labor represents a need, rather than a shift toward simple commodity production. Non-family labor was employed to augment family production.

By no means did every household rely on outside labor. In fact, less than half the households did so in 1860 . Those households that used outside labor need to be examined to determine the household structure that was augmented by such labor. Further, the nature of the greater society in which they appeared must be remembered. The presence of boarders to augment family labor, in this regard, does not indicate a shift to commodity production. Farmers continued to produce the same array of crops, livestock, and other goods as they had the in $1850 \mathrm{~s}$. Production was still geared for family consumption, not commercial purposes. The social structure was not always able to reproduce the necessary workers for the primary economic unit, and community was becoming increasingly unavailable due to the death and departure of household heads. Where family labor was deficient, hired labor was used. In other words, oregon was populated by young families. Scarce labor in the early years was overcome by the development of reciprocal labor among the neighbors. As labor became more available, and while the children were growing up, outside labor was employed. Once the children attained the age where their labor was available, they were employed. 
First, those households that used outside labor apparently lacked sufficient family labor. Female children outnumbered male children in the 1853 Marion County census. The lower number of male children translated into a lower number of male agricultural laborers as the children matured. Non-family labor was employed to resolve shortages within the nuclear family. For instance, the John A. Johns household contained a saddler and a farm laborer in 1860. This household contained only one son who had attained the age of 15 . The other children ranged in age from one to thirteen: there were eight children in the household that had to be provided for. Since Johns was himself a saddler, the presence of another saddler suggests that the second was an apprentice.

The Morgan Savage household used the labor of two outsiders to provide for the needs of his young and growing family. Unrelated female domestic labor was used by the William Roberts family to help Hannah Roberts provide for their two grown sons who remained at home. ${ }^{3}$ The use of outside labor to augment family labor was part of the strategy that the family employed for subsistence. Each family constituted a productive unit. As the line between generations became established, each family concentrated upon itself, and labor exchange between households diminished. Deficiencies in family labor, that once were filled by community reciprocity, were filled by hiring 
outsiders to fill the gap.

It is unknown how all laborers were compensated, although some examples exist. For instance, the samuel Parker household employed a laborer who was compensated by a gift of land, 270 acres for one dollar. ${ }^{4}$ The passing of land by Parker indicated that he believed non-family labor was included in family strategy. In addition, some received a wage. The older Smith's account book provides some insight into compensation of farm labor. On March 28,1863 , note is made of $\$ 22.50$ to overhulser. Later in the book, on the page that contains the figures behind the payment is found: "Overhulser has worked up to this

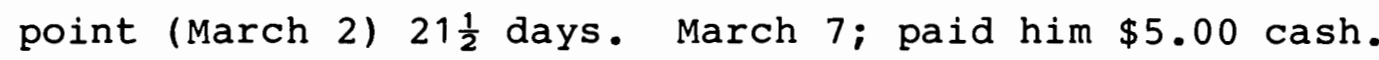
March 28; by $5 \frac{1}{2}$ days $5.50 "$ smith then computed the wage. For the 27 days worked $\$ 27.00$ minus the $\$ 5.00$ paid on March 7 equals $\$ 22.00$. Smith pays for labor at the rate of $\$ 1.00$ per day. 5

The use of outside labor in 1860 was due largely to the relative youth of the neighborhood. Therefore, as the neighborhood aged, the need for labor decreased. In 1870 , there were only 20 outsiders, located in twelve households. Half of these outsiders were laborers residing in the homes of families with children too young to be employed as farm hands. 6

By 1880 , it becomes entirely clear that outside help was sought to fill the deficiencies in family labor, as 
the majority of the 15 outsiders present were in households where the children had grown and moved on. The remainder were in households where one of the parents had passed away. $^{7}$ In 1895 only one household employed outside labor. 8 The surviving members of the first families in oregon were provided for by their grown sons and daughters. The use of outside labor among the second generation households was rare. Four households are known to have had outside labor in 1870. One of the households, James Crump's, contained a nurse and a female boarder employed as a dressmaker. The crumps had no children. Crump died later in 1870. The pattern of labor augmentation evident in the Crump household was duplicated among other households of the second generation. The majority of the 13 outsiders in the homes of the second generation in 1870 were boarders. In fact, the cartwright home contained an entire second family of eight. The remaining boarders were engaged in specific tasks geared toward a family need. 9

By 1880 the use of employed labor in the households of the second generation continued the pattern established in the households ten years earlier. The census for that year shows an equal number of men and women (eight) employed by the younger generation. The majority of the boarders were family members such as nieces and nephews. Those outside the family in these households were employed 
in traditional practices. The women were primarily engaged as cooks or in other household work. The men were split between apprenticeships and farm labor. ${ }^{10}$ The children, once established on their own farm, or in their own household, used outside labor sparingly. This pattern was repeated for each household, creating a situation where reciprocal labor between households became unavailable. The nature of the shift in household economic strategy is exemplified by the land transfer strategies used by the Donation Land pioneers.

In Marion County, the land market that developed in the early 1850 s was fueled by the sale (in part and whole) of many of the Donation Land claims. One-third of the Donation land pioneers sold their claims entirely before 1859, producing a large amount of land available for purchase in Marion County. The settlers who remained in Marion County were in an advantageous position to speculate in the land market. Many in Smith's neighborhood took advantage of that option. In fact, twenty-five (67\%) of the settlers in the neighborhood made purchases in varying amounts over the three decades encompassed by this study. Sixteen held a portion of their purchased land through 1883.

of the twenty-five settlers in the neighborhood who purchased agricultural land in Marion county, just over half (13) bought tracts that totaled less than 500 acres. 
Eight purchased between 600 and one thousand acres. The remaining four purchased tracts totaling more than 1100 acres, with the largest parcels totaling 1557 acres. The settlers were either speculating or purchasing land to strengthen their family's resources.

One-third of the settlers who made purchases engaged in land transactions that were beyond the amount of land needed for their own agricultural production (more than 600 acres). These settlers, it appears, were speculating. The remaining settlers who made purchases bought between 1 and 600 acres. They viewed the land in agricultural terms and increased their family's resources.

Sixteen from the group of settlers who made purchases held some of the land in 1883, indicating that they were buying land as a family resource. Of the sixteen, seven held less than two hundred acres while four had acreage in excess of 600 acres. This land was transferred to their offspring.

The third aspect of the land market in Marion county centered in the growth of Salem proper. Events in Salem in 1851 (the year salem became the territorial capitol) promised long-term prosperity and insured long-term growth. The settlers in Marion County were well positioned to take advantage of this prospect and began to purchase town lots from William Holden Willson and his wife chloe. The founding of Salem is traceable to the Methodists, 
who in 1841, moved from Mission Bottom to Chemeketa (the name Salem was first known by). In 1845, willson was charged by the board of the Methodists' Oregon Institute to sell town lots. In 1851, the Democratic party was successful in making salem the territorial capitol. Existing land records begin in 1853 and show the rapid growth of the salem land market.

Not all of Smith's neighbors desired (or were able) to engage in the land market. Two-thirds, however, purchased at least one lot. The majority purchased fewer than ten over the thirty years studied. Five purchased in excess of twenty lots, while two purchased land that was eventually platted as additions to the city of salem. While their involvement was modest, one-third of smith's neighbors made land dealing their occupation.

Donation Land pioneers' land disposition strategies affected the development of oregon. The question here arises as to whether holdings of this size, and variety, were necessary for survival of the primary social unit, the family. Donation Land pioneers who passed land to their sons and daughters used the land as a family resource. Other Donation Land pioneers used their land to increase their own wealth and were less likely to pass land to their children.

Donation Land pioneers in the Smith neighborhood provided land to the sons and daughters twenty-four 
different times. Fourteen (388) of the household heads, provided land to their offspring. An equal number left Marion County having disposed of their land. Nine of the settlers had their estates probated after their death and portions of their estates went to family members in the form of real estate or cash. 11

Moreover, every one of the twenty-three pioneers who remained in Marion county until their deaths passed at least a portion of their estates to their children. Three of the settlers that removed provided land for one or more of their sons and daughters. The Donation Land pioneers who remained farmers (48\%) passed agricultural land to their children during their lifetimes. The children of Donation Land pioneers who sold their lands to purchase other lands (28\%) received town lots and cash legacies. The Donation Land pioneers who remained in Marion County $(708)$ either farmed or lived in Salem until their deaths. The children of the farmers were more likely to persist than children of pioneers who dealt in land as an occupation.

Time brought many advances and changes to salem. Farmers in the neighborhood were aware of the changes going on around them. Their material life on the fringes of a commercial center was different, but the basic working of the pioneer society and economy persisted. Fabritus Smith's life illustrates these social and 
economic changes. In his 1854-1855 account book, Smith describes a pattern of reciprocal labor exchange. By 1863 he was paying for labor because his household did not produce the necessary labor. His 10 year old son died in 1859. His next son was born in 1862. Smith continued to pay for labor throughout 1874, the last year he kept note of his accounts. Smith's son Hamlin began keeping note of his daily activities in 1878. At sixteen years of age, the boy appears to have been involved in most aspects of the farm. The younger smith's activities included helping his father through 1896, the last year Hamlin kept notes while his father was alive. 12

The pattern of family labor employed by smith was indicative of the household mode of production. The family was the productive unit. The younger smith's daily activities in 1878 varied little from his father's in the 1850s. They both were aware of the season, as exemplified by their seasonal pattern of activities. Hamlin plowed, spread manure, and sowed in the late winter and spring. He planted the family garden with the same eye to the seasons. The late summer and fall were spent in harvesting crops and hauling them. Chores and odd jobs occupied his time when work with crops was completed. The winter months were spent fencing the Smith property, as well as clearing land. In addition, much time was spent with animals. 
The overall production of the farm changed little. Hamlin Smith still practiced diversified farming. He planted a mix of grains and orchard crops. He raised animals for meat and other products such as wool and leather. And he cut wood for use as fuel and shelter. as well as sale. 13 The pattern of Hamlin Smith's activities established in 1878 continued through 1902 , the last year of his diary. 14

The relationship between Hamlin Smith and the products he exchanged remained, as in his father's case, focused on use, not market, value. In 1863, the elder Smith noted how much cash he had on hand at the beginning of each month. His notations pertaining to its distribution and accumulation indicate that its use was his primary motivation for keeping notes. The example provided by his June account clarifies the point. During that month Smith received money from his position as road supervisor, and from the sale of wool. Three notations "collect" are an unknown source of income, and most probably derive from his position as road supervisor. Smith used the money to provide goods that his family needed such as "oil and sugar". He made additional outlays for payment of road hands and "church". The use-values of the money becomes apparent when the balance is reckoned. His cash on hand June 1 was $\$ 91.85$. His balance at the end of the month was $\$ 27.81 .^{15}$ Smith did not practice "profit 
maximization."16

The elder Smith's economic life was simple. He showed credits in the form of goods sales, road work, and payments on accounts between himself and others. His debts were in the form of paying road hands, payment on accounts with neighbors, and goods and services that his family needed and could not produce. His simple economic life remained geared toward social need.

The goods Smith exchanged for cash were those produced beyond family need, surplus goods. Smith used the cash to obtain goods that his family was unable to produce. Smith sold surplus agricultural products, such as fruit, livestock, wool, grain, and wood. Smith's services were exchanged with the needs of the community in mind. He served as road supervisor in 1863 and 1864. The existence of accounts between Smith and others, that were not settled annually, indicate the social need for exchange. The total of Smith's credits was equal to or greater than his debts. The economy was still indicative of a household mode of production.

Smith's 1863 account book does not provide much insight into the life of his wife, Vergelia. However, some speculation is possible due to the presence of some purchased goods, and the absence of others. For instance, the smith household did not make their own cloth. Wool was sold, and calico was purchased. Further, there was 
no reference made to butter and cheese money entering the account of Smith, and there was also no reference to their purchase.

Eight years later there was no evidence of a change in the basic workings of the economy. Smith's accounts for 1871 are very similar to the picture drawn for 1863. However, two differences appear. The first, was that Smith was no longer road supervisor, (and showed increased activity in his "wood account".) The second change is seen in the intensity of his dealings, especially in the sale of land.

Smith's involvement in wood sales is reflective of the employment of his own energies. The time he once spent doing road work was spent, in the 1870s, chopping and hauling wood. His work still filled a social need since wood was the primary fuel source. The income derived from this activity was used to procure goods and services that were not provided by household labor.

Fabritus did not practice a trade or profession that he could teach his son. Hamlin followed in his father's footsteps. Hamlin learned farming from his father. In fact, the younger Smith's accounts indicate that he ran the family farm after his father's retirement. In the early 1890s, Hamlin had received the farm, through gift and purchase, from his father. 17 Then, in his early thirties, Hamlin married and began to farm the 100 plus 
acres he received from his father. The farming activities of the son were very similar to those his father had practiced through his tenure as a farmer.

Through the younger Smith's account book of 1894 one can reconstruct his life as a farmer. Although his descriptions are terse, and his monetary accounts are incomplete, his annual duties closely resemble his father's practices. Hamlin's agricultural activities were restricted by the dictates of the seasons. He produced the same complement of goods that were the mainstay of his father four decades earlier. Hamlin made repairs around his property in the fall, winter, and early spring. He plowed and sowed crops when the ground had thawed and was ready for cultivation. When not behind the plow, or spreading seeds, he worked his sheep. The farmers in the Smith family relied on wool production since the introduction of sheep in the 1850s. Likewise, he possessed cattle and horses for their labor power. Hamlin and Dessie, his wife, were provided fruits and vegetables from a garden and orchard. Notations contained in the account book indicate that the family consumed the produce of the farm. 18

The Smith family exhibited the lineal family nature described for the neighborhood. Fabritus had remarried after the death of Vergelia. His daughter, Veleda, married and eventually settled to raise a family near the elder 
Smith. An unmarried sister remained at home. Each of these relatives was present in the life of Hamlin and his wife. They took supper, visited, and spent the day with one another. Other common activities for the family included church attendance and other Sabbath festivities. In addition, Hamlin worked on the farms of both his brother-in-law and father. His wife helped Veleda and her mother-in-law feed the men on these occasions of reciprocal labor. Hamlin and Dessie made notations on August 8 that exemplify the reciprocal nature of the lineal family labor system. Written in two different hands we find "help Adam thrash help Mrs. Ohmart cook for thrashers."19 Reciprocal labor was a very integral part of the Smith family's economic strategy, but by the $1890 \mathrm{~s}$ did not extend beyond the family line. The only exception was when Hamlin did some hauling for the preacher. The younger Smith's economic activities were markedly different than his father's. However, important similarities persisted. Hamlin sold very little of his agricultural produce. The goods he sold in 1894 were limited to wool, wood, a small amount of grain, livestock, and eggs. Smith sold surplus produce to acquire goods that were beyond his family's production abilities. He purchased sugar, salt, and articles of clothing. The difference between father and son appears to be the lack of notes and accounts. This indicates one of two things. 
Either the young Smith was unable to establish credit, (or the merchants were unwilling to extend it) or he did not need credit. In any event, each notation indicating an exchange is accompanied by a dollar amount. With the absence of running accounts in Hamlin's book (as opposed to his father's), it appears that salem merchants were operating in a cash economy. 20

Hamlin Smith's activity in that economy was limited. He still produced goods on his farm for household consumption. The dollar amounts affixed to exchange represented the rise of the cash economy in Salem. The production of his lineal family remained directed toward the use-value of the products. Hamlin entrenched himself in his family's productive power even as the rise of the cash economy changed his world.

By 1902, the changes do not appear to have swept the younger Smith away. Smith stemmed the tide by entrenching himself within his lineal family. 21 The passing of the elder Smith in 1898 brought more land and resources into his hands. However, the added wealth did not change the focus of Smith's farming activities. The reciprocal nature of labor exchange between Smith and his brother-in-law Adam became stronger. The additional labor of a nephew on the farm allowed smith more leisure, but his exchanges do not show a correspondingly high increase. Rather, Smith and his wife spent more time, 
on average once a week, visiting neighbors and going to town. Smith was also free to travel.

The pattern established by the Smiths represents a portion of the greater oregon population. Recipients of Donation Land Claims held a commanding influence over the lands of Oregon. The social structure they developed continued through the period of initial settlement into the twentieth century. The Act of Congress gave the pioneers of Oregon the advantageous position of control of the land, the strategy they used to dispose of that resource would be the determining factor upon the persistence of the economic and social structure they created.

Three case studies will demonstrate the previous findings. The first example will look at a settler that fits the notion of having been bound to the community, comprising eighteen (48\%) Donation Land pioneers. The second shows one family using the land for immediate capital that allowed them to leave oregon to pursue another venture. This strategy was incorporated by eleven (30\%) of the Donation Land pioneers. The final case examines a settler who was occupied by land deals. Eight Donation Land pioneers (22\%) purchased lands in excess of 1000 acres (or twenty town lots).

The first example is that of Fabritus R. Smith and exemplifies the pattern of property transactions of the 
majority of neighbors. Smith migrated to oregon as a single man in his late twenties. He met and married a girl from the neighborhood and established his family in the rolling hills south of Salem. His land dealings were on a small scale, purchasing two town lots and 245 acres of other agricultural land. His purchases amounted to $\$ 2,075$ between 1856 and 1872 , the largest expenditure coming in 1872 .

In addition to the land that Smith purchased, he sold portions of his 625 acre Donation Land Claim. By 1860 , he had alienated one hundred twenty-five acres of the Land Claim for $\$ 500$. At the same time he made his first purchase of agricultural land, 135 acres, for the same price. This was essentially an exchange, for both transactions involved the same person and price. Both parcels were in the same township. 22

Smith eventually sold a portion of the land in 1880 to his daughter, Veleda, for $\$ 1.00$. Smith established his daughter, after her marriage to Adam ohmart in 1877, on the purchased farm. The ohmarts remained in Marion county.

Smith established his entire family on lands of their own. His only living son, Hamlin, purchased land from his father in 1888 at the age of 26. From his father's government claim Hamlin bought 104 acres for $\$ 1000$. The older Smith also sold additional land to his daughter 
and son-in-law. Lands adjoining the earlier gift were sold to the ohmarts for one thousand dollars in 1889. Hamlin also received a gift of 38.75 acres from his father in 1892, long after his father had retired. His youngest daughter, clara, unmarried at the time of his death, waited until the execution of his will to receive the house, where she lived. 23

The land dealings of Smith also signify a social need. All of the prime agricultural lands were granted under the terms of the Donation Law. Therefore new arrivals to the area had to purchase farms from the original settlers. Smith showed two transactions involving George Litchfield. In 1870 , he sold 6 acres for $\$ 600$. Later, in 1877 , he sold another ten acres at $\$ 50.00$ per acre. The Smith-Litchfield transactions are of particular interest because in $1854 \mathrm{Smith}$ was corresponding with a Litchfield, presumably the parent of George. George Fabritus Litchfield was born in 1840 in Connecticut. The obvious namesake of Smith, Litchfield was in oregon as early as 1863, when he appeared on the road collection rolls. 24 He remained propertyless, according to the tax assessment rolls, until his purchase from the land claim of Smith.

Smith was described as "a successful farmer in Marion county" 25 and as such accumulated modest wealth. At the time of his death, his estate was appraised at $\$ 2,000$ 
personal and $\$ 10,000$ real. Smith was close to his son Hamlin. Less than a year before his death, the older Smith wrote to his son that "I have ment to do right ... and I love you as a father ought." The letter offers insight to the affinal connection between father and his children. The letter sought to define the terms of his will and explain past actions, to impart the wisdom of his years, and to council his son, while directing him to perform specific duties as the executor of the estate. ${ }^{26}$ Besides professing fatherly love, the older Smith provided for the future economic needs of his children. The will directed that the three children of Fabritus and Vergelia Smith, (Vergelia Smith preceded her husband in death) divide the property remaining after the final settlement of debts against the estate were settled. Further the will made specific provisions for Hamlin and Clara. Hamlin received the livestock and hardware, clara got the house, to share with Smith's widow (he remarried in 1877) furniture, and 15 acres. The will directed Hamlin to "provide for clara and the widow in the same manners as now." The will stipulated that the widow was to receive none of the estate and that Smith's heirs were to receive none of the widow's estate. 27

Those pioneers who did not persist are represented by the land disposition pattern used by Thomas Powell. Powell was born in England in 1811 and arrived in oregon 
by 1846. Powell staked his claim on september 15, 1846. on Christmas Day, 1850, he married his second wife, Arilla, in Salem under the direction of David Leslie. Powell had three children from his previous marriage. Thomas and Arilla were blessed with the arrival of a daughter before 1850. He declared his intention to become a United states citizen and received patent to 640 acres of timber-margin in Marion County. A blacksmith by trade, Powell, was a valuable asset in the young community; however, by 1860 he and his family had left Marion county for neighboring Linn County. Powell's reasons for moving to Linn County do not survive. They used the land for immediate capital that allowed them to move to another part of oregon, or another state to pursue another venture Powell's tenure in Marion County was profitable. After twelve years settlement he sold his family's land claim on May 8, 1858, for $\$ 3,500$. In addition, he had purchased from the willsons a considerable amount of town land, including the entirety of block 33. For nineteen lots he paid $\$ 1,000$ on December 11,1855 . Within three years, Powell had sold all the lots for $\$ 4,455.28$ In 1858 he left Salem. Powell represents of that portion of the population for whom initial settlement was temporary, an opportunity to practice a trade, and accumulate property, while always looking for opportunities elsewhere. This strategy was incorporated by eleven (308) 
of the Donation Land pioneers.

The final study focuses on one of the settlers who moved to town and dealt in real estate. Eight Donation Land pioneers (22\%) purchased lands in excess of 1000 acres, or twenty lots, and are thus deemed real estate investors. Cyrus Reed illustrates real estate speculation in Oregon. Reed arrived in Oregon from California in December of 1849. He appeared in Washington County in the 1850 United states Census, and is known to have had business in the Portland area. He married his first wife, Lucinda, in Portland in 1850. Sometime before 1852, he relocated to the Salem area and established a Donation Land Claim. He farmed and improved the claim for four years before moving on to the mercantile business. By 1860, he had established a rather large real estate holding, $\$ 80,000$ according to the 1860 United states Census.

Reed entered the land market in 1856, with the purchase of a fractional lot, and expanded from there eventually to have an addition to the city of salem platted from his purchases. Always public minded, "one of his public ventures was the building of the opera house in Salem in 1869."29 However, Reed failed in business eventually; he listed no property in the 1870 United states Census, nor did he purchase any real-estate between 1870 and 1876. Reed plied his trade, eventually recouping 
his losses, and engaged in familiar business practices until he removed from Salem in 1885.30

The children of Donation Land pioneers lived differently than their parents had. The community their parents established to organize local production declined in importance with the rise of lineal families, and the depletion of connections. Further, as the children matured, so did Salem as a commercial center. Members of the younger generation who remained farmers entrenched themselves within their lineal families to produce a subsistence and resist commercial agriculture. Farmers who possessed land were more likely to stay in Marion County than their landless neighbors. Discontented members of the neighborhood left. The neighborhood persisted alongside a commercial entrepot in altered form. 


\section{CONCLUSION}

The Donation Land Law created an advantageous situation for those Americans who immigrated to Oregon in the 1840s and 1850s. The law gave them command of the lands of oregon. The settlers were predominately from the Middle West. Their perceptions and experiences shaped Oregon for two generations.

The social structure they brought centered around the family. Farmers were pushed to oregon by the collapse of commercial agriculture in the Ohio River Valley. They created an economy tempered by the flames of economic panic. Their local economy was based on barter exchange that later gave way to cash. Their resistance to commercial agriculture persisted to their children. The community they created to direct local production was replaced by lineal families producing for themselves. settlers were also drawn to oregon by the prospect of possession of land adequate to their family's needs. They created a society and economy that was in many respects contrary to that of the Midwest. In fact, oregon farmers were hesitant to produce for agricultural markets created by the California gold rush. Despite their proximity to a commercial center, farmers in the 
neighborhood continued to resist the commercial development of oregon to 1900. The farmers in Smith's neighborhood expanded into markets slowly. The land law created an agricultural economy dominated by large family farms, communally intertwined to produce a level of subsistence. The area under cultivation on these farms was enough to support a family. Due to the constraints of labor, limited to the family, farmers were uninterested and unable to provide produce for far-off markets. The unwillingness, and inability, of oregon farmers to pursue commercial agriculture fit well with their desire to emphasize production for family consumption needs. Not every settler who received a Donation Land claim shared the view of the majority. Some saw the donation of land by the government as a means to ends other than farming. But it was those who stayed on the land who influenced oregon for many years. And their purpose was to pass a compentency along to their children.

The children of the Donation Land pioneers lived differently than their parents had. However, the economic structure developed by their parents--the settler population--was ingrained in the lives of the children. Diversified farming remained the common practice among the second generation farmers. Without doubt, the presence of merchants in salem created changes in the local economy. The use of notes, barter, and credit diminished as the 
cash economy grew. Nonetheless, the farmers of the second generation did not change their objective; only their strategy changed to meet the new economy. In order to maintain production for household consumption, they entrenched themselves within their lineal family to produce a subsistence. The turn of the twentieth century found an agricultural society that was within a cash economy, but not completely a part of that economy. The use of cash did not change the dominant position of the lineal family.

The first two generations of rural society in oregon were very similar. Their similarity stands in stark contrast to the society and economy of the Midwest. Two recent studies of Midwestern communities show how the area that oregon settlers removed from differed. John Mack Faragher, in Sugar Creek, examined life on the Illinois prairie He found settlers in community on sugar Creek. He noted the changes and developments within the community as farmers became involved in markets. ${ }^{1}$ Don Doyle, in The Social order of a Frontier Community: Jacksonville, Illinois 1825-70 studied town life on the frontier. He found the social order of Jacksonville directed as much toward sapitalism as to community. Collective material interests strengthened the community. 2 In 1902, Hamlin F. Smith, Oregon farmer, and son of oregon pioneer Fabritus R. Smith, woke-up in his house. 
The house was on land that he had purchased from, or been given by, his father. His father had received the land as a reward for venturing to oregon in the 1840s. Hamlin was born on the land, and he watched both of his parents die there. That land was the center of his world. He never ventured far from that world, taking what education he received in a school in the neighborhood. Approaching forty years of age, he had been witness to many changes. The scattered glimpses he left of his life in the hills south of Salem indicate that he changed less than his surroundings. Literally in the middle of his life, Hamlin would witness many more changes.

No doubt, Hamlin had been told the story of the overland trek, how his father, a single man in a large train, had "seen the elephant," the popular expression from that time. With his two surviving sisters, he had probably heard of the difficulty faced by the settlers once they reached their destiny, the uncultivated grasslands of Oregon. The children also heard of the friendships and fellowship that developed out of necessity, as each settler family labored to obtain a subsistence. They heard how neighbor helped neighbor, and how the community gathered to help their father construct the barn that sheltered the family livestock during the occasional Oregon snowstorm. Other, less romantic, aspects of life in the early days of oregon, may have been omitted 
by their father. Far from apologia, the reminiscences of Fabritus, if they actually occurred, served to direct his children. But even if Fabritus had not actually told stories to his children, they doubtless learned by watching him become a successful farmer in oregon. That their father's example must have affected them is evident in their material life. 
NOTES

INTRODUCTION

1. James Lemon argues in "Early Americans and Their Social Environment," Journal of Historical Geography 6 (1980), pp. 115-131 that "when European settlers stepped ashore at Jamestown and Plymouth, they were already participants in a society that encouraged accumulation...." p. 119. Conversely, James Henretta "Families and Farms: Mentalite' in Pre-Industrial America." The William and Mary Quarterly, 35 (1978) pp. 3-32, maintains "commercially oriented agriculture began to develop after 1750, in response to lucrative urban and European markets for American grain." p. 16.

2. The outlines of the debate within the genre of social history are clearly drawn in Allan Kulikoff "The Transition to Capitalism in Rural America." The William and Mary Quarterly 46 (1989) pp. 120-144. For an excellent example of the social historians see James Henretta, "Mentalite'," and Christopher Clark, "Household Economy, Market Exchange and the Rise of Capitalism in the Connecticut Valley, 1800-1860." Journal of Social History, 13 (winter 1979) pp. 169-189. The arguments behind the market historians' interpretations are best presented in Michael Merrill, "Cash is Good to Eat: Self-Sufficiency and Exchange in the Rural Economy of the United States." Radical History Review 3 (1977) pp. 42-71; Hal Barron, Those Who stayed Behind: Rural Society in Nineteenth-Century New England (Cambridge: Cambridge University Press, 1984), and Lemon, "Early Americans"

3. See Kulikoff, "The Transition to Capitalism," for explanation in greater detail of Marxian theory of exchange; also Merrill, "Cash is Good to Eat."

4. Gordon B. Dodds, The American Northwest A History of Oregon and Washington (Arlington Heights, Illinois: The Forum Press, Inc., 1986) p. 46. and Keith A. Murray: The Role of the Hudson's Bay Company in Pacific Northwest History in G. Thomas Edwards and Carlos Schwantes (eds.), Experiences in a Promised Land, (Seattle: University 
of Washington Press, 1986).

5. John A. Hussey, Champoeg: Place of Transition, (Portland: Oregon Historical Society Press, 1967), pp. $112-114$.

6. Felix Flugel, Readings in the Economic and Social History of the United States, New York: Harper and Brothers, 1929.

7. The Congressional Globe, 31st. Congress, 1st session, pp. $1739-1744$ and 1839-1847.

8. Ibid., 33rd. Congress, 2nd session. An Act of July 17,1854 allowed sale prior to patent upon four years residence.

9. Jerry A. O'Callaghan, The Disposition of the Public Domain in Oregon (Washington, D.C.: United States

Government Printing Office, 1960), pp. 31-33.

10. The Congressional Globe, 31st. Congress, p. 1077.

11. Henretta, "Mentalite'." p. 3-32.

12. Merrill, "Cash is Good to Eat." p. 63.

13. O'Callaghan, Disposition, p. 34.

CHAPTER ONE

1. Dorothy 0 . Johansen, "A Working Hypothesis for the Study of Migrations," in G. Thomas Edwards and Carlos

A. Schwantes (eds.), Experiences in a Promised Land (Seattle: University of Washington Press, 1986), pp. 40-50.

2. Thomas Jefferson wrote of the exalted position of the American farmer, when he wrote "Those who labor in the earth are the chosen people of God, if ever he had a chosen people, whose breast He has made His peculiar deposit for substantial and genuine virtue." Jefferson believed that husbandmen were not subservient because they were not dependent upon anyone else for their subsistence. Adrienne Koch, and William Peden, The Life and Selected Writings of Thomas Jefferson, (New York: Random House, 1944), p. 280 .

3. John Mack Faragher, Women and Men on the oregon Trail, (New Haven: Yale University Press, 1979), pp. 179-189.

4. Recent historical writing pertaining to the primary 
position of the family in nineteenth century rural economy includes, Henretta, "Families and Farms", Merrill, "Cash is Good to Eat", and Lemon, "Early Americans"

5. Melvin Clay Jacobs, Winning oregon, A Study of an Expansionist Movement. (Caldwell: Caxton Printers, 1938) p. 68. and H. K. Hines, D. D., An Illustrated History of the state of oregon (Chicago: The Lewis Publishing Co., 1893), p. 770 .

6. Hubert Howe Bancroft, History of Oregon 2 vols. (San

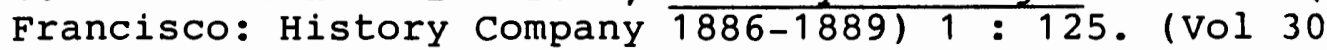
of HHB's Works, 39 vols).

7. Hines, An Illustrated History, p. 770 .

8. The daily life of an oregon farmer was determined by looking at the daily activities found in Fabritus $R$. Smith, "Account Book 1854-1858" Located in the University of Oregon Library, Special Collections Manuscript number A 191 .

9. The first two years of Smith's "Account Book", 1854 and 1855, consists of daily entries detailing his activities and the neighbors with whom he is involved.

10. H. O. Lang, History of the Willamette Valley (Geo. H. Himes Book and Job Printer, 1885), p. 588 .

11. Virgil K. Pringle, Diary (Oregon Historical Society Mss. Microfilm 1194).

12. Smith, "Account Book," August 1854 .

13. Smith "Account Book," December 1854; The "Account Book" for the years 1856 and 1858 consists of entries only on days that an exchange took place with cash amounts shown and a total for the year.

14. Smith's accounts indicate the use of barter and personal money. For larger historical significance, see Bettye Hobbs Pruitt, "Self-Sufficiency and the Agricultural Economy of Eighteenth Century Massachusetts" The William and Mary Quarterly, 41 1984, pp. 333-364. For distinction between self-sufficiency and subsistence. Also see Henretta "Mentalite" for nature of exchange outside market economy p. 15 .

15. Oregonian, April 24, 1852.

16. Ibid., July 17,1852 .

17. Ibid., April 10, 1858. 
18. Quoted in Arthur L. Throckmorton, Oregon Argonauts: Merchant Adventurers on the Western Frontier (Portland: Oregon Historical Society, 1961), p. 161. By primitive nature, I mean the lack of development of technology, for instance, the wooden plow, the cradle and the scythe used in agriculture.

19. Oregon Farmer, (August, 1858).

20. Sarah Hunt Steeves, Book of Remembrance of Marion County, Oregon Pioneers 1840-1860 (Portland: Berncliff press, 1927) p. 339.

21. Oregon Statesman, October 4, 1853.

22. Ibid.

23. Oregon Farmer, September 1859; December 1858 .

CHAPTER TWO

1. Don Harrison Doyle, The Social order of a Frontier Community: Jacksonville, Illinois 1825-70. (Urbana: University of Illinois Press, 1978) p. 93.

2. The Smith neighborhood is defined in this thesis as the fifty individuals with whom Fabritus smith dealt in 1854 and 1855 as noted in his account book. The names were culled from the existing record.

3. William Bowen, The Willamette Valley: Migration and Settlement on the oregon Frontier. (Seattle: University of Washington Press, 1978) pp. 52-54.

4. Manuscript Schedules, United States Census for Population, 1850 (Microfilm, Oregon Historical Society).

5. What I refer to as the life-cycle is defined in Richard Archer "New England Mosaic: A Demographic Analysis for the Seventeenth Century" The William and Mary Quarterly, XLVII (4) 1990. pp.477-502. He cites youth (under 10), childhood (10 to 18 years), young adulthood (18 to 30), middle-age (31 to 60) and old-age (60 plus)

6. Bowen, Willamette Valley p. 58 .

7. Marion County Census, 1853 (Microfilm, Oregon state Archives).

8. Ibid., lists (for the neighborhood) sixty-seven males over 18, forty-six females over 18, and 121 children. 
Total population 234 .

9. John Mack Faragher, Women and Men on the oregon Trail (New Haven: Yale University Press, 1979) pp. 34-39. Bowen, Willamette Valley, p. 56.

10. Jerry A. O'Callaghan, The Disposition of the Public Domain in Oregon (Washington D. C.: United States Government Printing office, 1960), p. 5 .

11. Jacobs, Winning Oregon, p. 52 .

12. Genealogical Material in Oregon Donation Land Claims 5 vols. (Portland: Genealogical Forum of Portland Oregon, 1959), contains information on the Oregon Donation Land pioneers. The age of the settlers when they married is important because it allows the historian to assess at what stage in the life-cycle men and women became established on their own farms. Genealogical the date of marriage. Comparing this information against the date of birth yields the age of marriage. The age of the settlers who married in Oregon is important to calculate since the law allowed more land to couples than single men. It is necessary to know if marriages occurred at an earlier age and hence if opportunities were greater for oregon settlers.

13. One of the most significant features of the oregon Donation Land pioneers is their dramatically high persistence rate. Historians examining other rural areas of the United states in the nineteenth century have found persistence rates indicative of the settlers contentment with their position. For example, Hal Barron, Those who Stayed Behind: Rural society in Nineteenth-Century New England (Cambridge: Cambridge University Press, 1984) examined a nineteenth century population in Chelsea, Vermont and found that farm operators had a persistence rate of 398 for the twenty year period from 1860 to 1880 . The same rate persisted from 1880 to 1900 . Further, John Mack Faragher, Sugar Creek: Life on the Illinois Prairie. (New Haven: Yale University Press, 1986), found Sugar Creek on the Illinois frontier had a twenty year persistence rate of about one-third of the heads of households. The findings of these historians are consistent with other nineteenth century rural societies and will serve as a base-line in defining the high or low persistence among oregon settlers. Persistence rates are figured by dividing the number of persisters by the number of survivors.

14. The importance of marriage and settlement is discussed in Bowen, The willamette Valley, pp. 28-42. 
15. Caroline C. Dobbs, Men of Champoeg, (Portland:

Metropolitan Press, 1932) p. 57.

16. Records, First Methodist Episcopal Church. Salem, Oregon.

17. Records, Protestant Episcopal Church, Salem, Oregon, First Methodist Episcopal Church.

18. Hines An Illustrated History, p. 770

19. Manuscripts Collection, Oregon Historical Society. mss 835 .

20. Jeanne Custer, and Daraleen Wade, The Marriage Records of Marion County, oregon 1849 to 1888,6 vols., (Salem: Willamette Valley Genealogical Society, 1979).

21. Peter G. Boag, Environment and Experience: Settlement, and Culture in Nineteenth-Century Oregon (Berkley: University of California Press, 1992).

22. Topographical Maps, Oregon Historical Society Library, Maps Department.

23. The study of the Donation Land claim recipients is limited to those settlers that compose Smith's neighborhood. The size of each claim was given in the Genealogical Material in Oregon Donation Land Claims. The claimants in Smith's neighborhood were extracted from the 1854-1855 Day Book. The conveyances and purchases for each settler were cataloged for the period 1853 to 1883. Within this period, most of the first generation settlers had passed-away and hence, their transactions were complete. Information on conveyances and purchases was found in the Index to Direct Deeds and the Index to Indirect Deeds, for Marion County, Marion County Courthouse, Salem, Oregon.

24. The Congressional Globe, 32nd. Congress, p. 1674.

25. Early settlement resulted in first choice of lands and allowed more time for improvements. Both variables had an effect on the value of property.

26. Index to Direct Deeds and the Index to Indirect Deeds, for Marion County, Marion county courthouse, Salem, Oregon.

27. Eighth Census of the United States, 1860,3 vols. (Washington D.C.: Government Printing office 1864-1865).

28. Ibid., Analysis yields 32 children born before 1842 in the households of the neighborhood. Thirteen remained 
to 1870

29. Ninth Census of the United States, 1870, 3 vols.

(Washington D.C.: Government Printing office, 1872). Marion County 1895 Census.

30. Tenth Census of the United States, 1880, 22 vols.

(Washington D.C.: Government Printing office, 1883-1888).

31. Marion County Census, 1895. Microfilm, Oregon State Archives reel $24 / 5287$

32. Ninth census, 1870. See also Faragher, Women and Men, p. 87, for discussion of gender roles.

CHAPTER THREE

1. Ibid., 1860 .

2. Ibid., 1850,1860 .

3. Ibid., 1860 .

4. Marion County, Oregon, Deed Records, Marion County Courthouse, Salem Oregon, vol. 14 page 142. (microfilm). To find individual transactions, the Index to Direct Transactions yields information regarding grantor, grantee, the date of the instrument and the volume and page number where the deed can be found.

5. F. R. Smith Account Book, 1863 .

6. Ninth Census 1870. Three households employed outside labor in both 1860 , and 1870 .

7. Ibid., 1880 .

8. Marion County Census, 1895.

9. Ninth Census, 1870 .

10. Ibid., 1880 .

11. Probate records, Marion County, Oregon state Archives. Records are incomplete for two settlers in the neighborhood.

12. Account Books of Hamlin F. Smith, various years 1878 to 1902 (Knight Library, University of Oregon Manuscript number A 191). 
13. Ibid., 1878 .

14. Ibid., 1902

15. F. R. Smith Account Book, June 1863.

16. For definition of "profit maximization" see Merrill, "Cash is Good to Eat" p. 63. Further, Merrill states

that "in simple commodity production the only condition is that the value of the inputs in the production process in never less than the value of the outputs; it is not necessary that sales exceed purchases." Smith's accounts do not meet this precondition of simple commodity production. Rather, Smith exemplifies what Merrill describes as the household mode of production, where a "producers debt equal that of their credits."

17. Marion County land Records Vol. 34, page 643, Vol. 52 , page 204

18. H. F. Smith Day Book, 1894 .

19. Ibid.

20. Ibid., 1902 .

21. Ibid.

22. Land Transfer Records, vol, 9, p. 148 and vol. 14 p. 189 .

23. Probate Records, Marion County, Oregon, Marion County Courthouse, File Number 1816.

24. Tax assessment records, Marion County, Oregon 1864, Oregon States Archives.

25. Hines, An Illustrated History, p. 797.

26. Letter. Fabritus R. Smith to Hamlin F. Smith, July 4, 1897. Fabritus Smith Collection University of Oregon, Knight Library Manuscript A 191.

27. Probate Records Marion County file 1816.

28. Land Transfer Records, vol. 34, p. 643 and vol. 52 p. 204 .

29. H. O. Lang, History of the Willamette Valley, p. 724 .

30. Hines, An Illustrated History, p. 588. 
CONCLUSION

1. John Mack Faragher, Sugar Creek: Life on the Illinois Prairie (New Haven: Yale University Press, 1986) p. 68.

2. Don Harrison Doyle, The Social order of a Frontier Community: Jacksonville, Illinois 1825-70. p. 96 . 


\section{SELECTED BIBLIOGRAPHY}

\section{Primary Sources}

Manuscript materials

Pringle, Virgil K. Diary. Oregon Historical Society, Microfilm, Mss. 1194.

Smith, Fabritus R. "Account Book 1854-1858." University of Oregon Library, Special Collections Manuscript number A 191.

Public Records

The Congressional Globe, 31st. Congress 1st. Session.

Land Transfer Records, Marion County, Marion County Courthouse Salem, Oregon. 1853-1883.

Marion County Census, 1853, 1895, Oregon State Archives.

Probate Records, Marion County, Oregon, Oregon state Archives.

Tax Assessment Records, Marion County, Oregon.

United states Census for Population, 1850, 1860, 1870, 1880

Church Records

First Methodist Episcopal Church, Salem, Oregon.

Protestant Episcopal Church, Salem, Oregon.

Books

Boag, Peter G. Environment and Experience: Settlement and culture in Nineteenth-Century Oregon. Berkeley: University of California Press, 1992. 
Bowen, William A. The Willamette Valley: Migration and Settlement on the oregon Frontier. Seattle: University of Washington Press, 1978.

Dobbs, Caroline C. Men of Champoeg, Portland: Metropolitan Press, 1932

Dodds, Gordon B. The American Northwest A History of Oregon and Washington. Arlington Heights, Illinois: The Forum Press, 1986

Doyle, Don Harrison. The Social Order of a Frontier Community: Jacksonville, Illinois 1825-70, Urbana: University of Illinois Press, 1978.

Edwards, G. Thomas. and Schwantes, Carlos A. Experiences in a Promised Land: Essays in Pacific Northwest History. Seattle: University of Washington Press, 1986 .

Faragher, John Mack. Women and Men on the Oregon Trail, New Haven: Yale University Press, 1979

- Sugar Creek: Life on the Illinois Prairie. New Haven: Yale University Press, 1986.

Flugel, Felix. Readings in the Economic and Social History of the United States. New York: Harper Brothers, 1929 .

Hines, H. K. An Illustrated History of the state of oregon. Chicago: The Lewis Publishing Co., 1893.

Hussey, John A. Champoeg: Place of Transition, Portland: oregon Historical Society Press, 1967.

Lang, H. O. History of the Willamette Valley. n.p.: Geo. $\mathrm{H}$. Himes Book and Job Printer, 1885 .

O'Callaghan, Jerry A. The Disposition of the Public Domain in Oregon, Washington D. C.: United States Printing office, 1960 .

Steeves, Sarah Hunt. Book of Remembrance of Marion County, oregon, Pioneers 1840-1860. Portland: The Berncliff Press, 1927.

Throckmorton, Arthur L. Oregon Argonauts: Merchant Adventurers on the Western Frontier. Portland: Oregon Historical Society Press, 1961.

Articles 
Clark, Christopher. "Household Economy, Market Exchange and the Rise of Capitalism in the connecticut valley 1800-1860," Journal of Social History XIII (winter, $1979)$, p. $16 \overline{9-189}$.

Henretta, James. "Families and Farms: Mentalite in Pre-Industrial America," William and Mary Quarterly. XXXVII (October 1980), pp. 3-32.

Kulikoff, Allan. "The Transition to Capitalism in Rural America, "The William and Mary Quarterly. XLVI (1989)

Lemon, James T. "Early Americans and Their Social Environment." Journal of Historical Geography. VI (April 1980), pp.115-131.

Merrill, Michael. "Cash is good to Eat: Self-Sufficiency in the Rural Economy of the United States." Radical History Review IV (Winter 1977), pp. 42-71.

Pruitt, Bettye Hobbs. "Self-Suffiency and Agricultural Economy of Eighteenth Century Massachusetts," The William and Mary Quarterly. XLI (1984).

\section{Newspapers}

Oregon Farmer. 1858-1863.

Oregonian. 1850-1859.

Oregon spectator. 1846-1852.

Oregon statesman. 1852-1859.

Maps

Metsker Maps. Metsker's Atlas of Marion County, Oregon. Tacoma, Washington, 1938

Topographical Maps for Marion County, oregon Historical Society Library Maps Department. 